\title{
Novel quinoxaline 1,4-di- $N$-oxide derivatives as new potential antichagasic agents
}

Enrique Torres $^{a}$, Elsa Moreno-Viguri ${ }^{a b}$, Silvia Galiano ${ }^{a}$, Goutham Devarapally $^{c}$, Philip W. Crawford $^{c}$, Amaia Azqueta ${ }^{d}$,Leire Arbillaga ${ }^{d}$, Javier Varela ${ }^{e}$, Estefanía Birriele ${ }^{e}$, Rossanna Di Maio ${ }^{e}$, Hugo Cerecetto ${ }^{e}$, Mercedes González $z^{e}$ Ignacio Aldana ${ }^{a}$, Antonio Monge ${ }^{a}$, Silvia PérezSilanes $^{a b^{*}}$

Authors' Affiliations: ${ }^{\mathrm{a}}$ Neglected Diseases Section. Drug R\&D Unit, Center for Aplied Pharmacobiology Research, University of Navarra, C/ Irunlarrea 1, 31008 Pamplona, Spain.

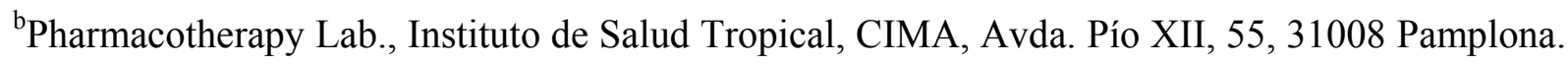
${ }^{\mathrm{c}}$ Department of Chemistry, Southeast Missouri State University, Cape Girardeau, Missouri 63701, USA. ${ }^{\mathrm{d} D e p a r t m e n t ~ o f ~ P h a r m a c o l o g y ~ a n d ~ T o x o c o l o g y ~ o f ~ U n i v e r s i t y ~ o f ~ N a v a r r a ~ C / ~}$ Irunlarrea 1, 31008 Pamplona, Spain. ${ }^{\mathrm{e}}$ Grupo de Química Medicinal, Laboratorio de Química Orgánica, Facultad de Ciencias-Facultad de Química, Universidad de la República, 11400 Montevideo, Uruguay.

ABSTRACT. As a continuation of our research and with the aim of obtaining new agents against Chagas disease, an extremely neglected disease which threatens 100 million people, eighteen new quinoxaline 1,4-di- $\mathrm{N}$-oxide derivatives have been synthesized following the Beirut reaction. The synthesis of the new derivatives was optimized through the use of a new and more efficient microwave-assisted organic synthetic method. The new derivatives showed excellent in vitro biological activity against Trypanosoma cruzi. Compound 17, which was substituted with 
fluoro groups at the 6- and 7-positions of the quinoxaline ring, was the most active and selective in the cytotoxicity assay. The electrochemical study showed that the most active compounds, which were substituted by electron-withdrawing groups, possessed a greater ease of reduction of the $N$-oxide groups.

KEYWORDS: Chagas disease; Trypanosoma cruzi; quinoxaline 1,4-di- $N$-oxide; mutagenicity; cytotoxicity; reduction potential.

\section{INTRODUCTION}

Chagas disease or American trypanosomiasis was first described by Dr. Carlos Chagas in 1909. It is a chronic parasitosis caused by the haemoflagellated protozoan, Trypanosoma cruzi ( $T$. cruzi), which is naturally transmitted by the triatomine hematophagous insect, Triatoma infestans. It is a major parasitic disease in Latin America, and it is endemic in 21 countries. [1-3] According to World Health Organization (WHO) data, Chagas disease affects about 8 million people and 100 million are at risk of infection, causing 13000 deaths annually. [4,5] In addition, it has an important socioeconomic impact on the endemic countries due to the fact that the chronic phase of the disease causes incapacity in infected people and due to the burden of high medical expenses placed upon the countries' governments. Moreover, in recent years, the incidence of the disease in non-endemic countries has increased due to new migration patterns. $[6-8]$

Despite the fact that it has been more than 100 years since the disease has been discovered, safe and effective treatments have yet to be found. The largest decrease in the number of people affected is due to the control strategies carried out against the disease vector. [3,9] Only two drugs have been commercialized, Nifurtimox (Nfx) and Benznidazole (Bzn), two nitroaromatic 
heterocycles, empirically discovered over three decades ago. Both drugs have a number of limitations, such as low activity in the chronic phase of the disease, emergence of resistance, and toxicity. Therefore, there is an urgent need to develop new, safe and effective therapeutic alternatives that are also cost-effective. [10-13]

Multiple anti-infective activities are well known for quinoxaline derivatives. [14, 15] Our group has vast experience in the synthesis and biological evaluation of multiple quinoxaline 1,4-di- $N$ oxide derivatives, having identified a broad spectrum of anti-infective activities. [16-26] The evaluation of several libraries of compounds led us to find a series with high in vitro activity against T. cruzi. [27] This finding allowed us to establish structural features for maintaining high in vitro activity against the parasite (Scheme 1).

\section{Scheme 1}

Continuing with the optimization of the structure-activity scheme planned by our working group, eighteen new quinoxaline 1,4-di- $N$-oxide derivatives, series 1 (1-9) and series 2 (10-18) (Table 2), were designed and synthesized. In order to carry out the synthesis, a traditional method and a new microwave-assisted method optimized by our group were used. The use of this new synthetic method was necessary due to the limitations encountered during the traditional synthesis. Microwave-assisted organic synthesis is an up-and-coming technique in medicinal chemistry and offers a number of important advantages. [28-31] The newly synthesized derivatives were modified at position 2 of the quinoxaline ring, possessing an ester group instead of a ketone group. These compounds were then evaluated against Tulahuen 2 strain of T. cruzi, using Nfx as the reference drug. 
In previous works, the presence of the $N$-oxides significantly potentiated the activity against $T$. cruzi, which may indicate the importance of a bioreduction or metabolization process of these groups by specific enzymes within the activity of these types of derivatives. [18, 27, 32] However, the mechanism of action through which these derivatives carry out their activity is unclear. In previous studies, an inhibition of mitochondrial dehydrogenases was demonstrated and it was also observed that benzofuroxan derivatives containing $N$-oxide cause a mitochondrial membrane depolarization in T. cruzi. [27, 33, 34]

In order to shed some light on this subject, a study was conducted which involved the measuring of the reduction potentials of the $N$-oxide groups in different synthesized derivatives and selected analogues. This experiment allowed us to conduct a study regarding the relationship between structure, $N$-oxides potential reduction and anti-T. cruzi activity. The aim of this study was to corroborate the importance of $N$-oxide reduction in biological activity and select the best substituents so as to find new leaders with higher activity and selectivity.

To evaluate the preliminary toxicity profile of the new derivatives, the cytotoxicity, the selectivity against the parasites and the mutagenicity were studied. [35]

\section{RESULTS AND DISCUSSION}

\subsection{CHEMISTRY}

Eighteen new quinoxaline 1,4-di- $N$-oxide derivatives were prepared using a variation of the Beirut reaction, in which the corresponding benzofuroxan $(\mathrm{BFX})$ reacted with the appropriate trifluoroacetoacetate (INT) so as to obtain the target compounds (Scheme 2). In the derivatives from series 1 (1-9), a $-\mathrm{CO}_{2} \mathrm{CH}_{3}$ group was introduced into the 2-position of the quinoxaline ring 
which was unsubstituted or substituted by different electronic substituents in the 6- and/or 7position of the heterocycle. Chloro, fluoro and trifluoromethyl were used as electronwithdrawing groups, whereas methyl and methoxy were used as electron-donating groups.

\section{Scheme 2}

Derivatives of series $2(\mathbf{1 0 - 1 8})$ possessed a $-\mathrm{CO}_{2} \mathrm{CH}_{2} \mathrm{CH}_{3}$ group in the 2-position and the same variety of substituents in the 6- and/or 7-positions of the heterocycle position as in series 1 . The starting compounds, 5-substituted or 5,6-disubstituted BFXs, were obtained by previously described methods. [36] Commercial reagents were also used. The new derivatives were prepared using two different synthetic methods, as shown in Scheme 2. In the first, a traditional synthetic method normally used by our group in which the BFX reacts with INT using acetone as solvent and sodium carbonate as base at room temperature, was carried out (METHOD I). This synthetic method has several important limitations. Mainly low reaction yields, long reaction times and complex purification. We attempted to optimize the synthetic method by conducting the reaction at $40-50{ }^{\circ} \mathrm{C}$ in an oil bath. However, with an increased temperature, the occurrence of by-products also increased, making purification difficult. Consequently, a new strategy of synthesis, microwave-assisted organic synthesis (MAOS), was attempted. A variation of Beirut reaction by microwaves irradiation, in which toluene was used as solvent and triethylamine $\left(\mathrm{Et}_{3} \mathrm{~N}\right)$ as base, was performed (METHOD II) (Scheme 2).

In order to determine if the microwave-assisted method offered advantages, the synthesis of nine of the new derivatives was performed in duplicate and two strategic parameters, reaction yield and reaction time, were compared. Compounds 6-8, 10-12 and 14-17 were synthesized using both of the proposed synthetic methods. As shown in Chart 1, the use of the new microwave- 
assisted synthesis method increased the reaction yields. The largest increase was observed in compound 16, where the yield increased more than 20 times, from $1 \%$ to $22 \%$. The results suggest that derivatives with halogen substituents at positions 6 and/or 7 of the quinoxaline ring react better using the microwave method.

The increase in yield was also influenced by easier purification method of the final product. Moreover, this resulted in a reduction of the quantity of solvent needed, with economic and environmental advantages.

The new optimized microwave-assisted synthesis method also permitted significantly reduced reaction times. As can be observed in Table 1, the data indicate a huge decrease in reaction times when using microwave irradiation. For example, compound $\mathbf{1 2}$ requires seven days using the traditional method while the new microwave method reduces the time to 52 minutes, representing a decrease of almost 200 times in the required reaction time. These observed reductions in reaction times are a key advantage of the optimized microwave method compared to the traditionally used method.

\section{Chart 1}

\section{Table 1}

\subsection{IN VITRO ANTI-T. CRUZI ACTIVITY}

The in vitro activity evaluation of 18 new quinoxaline 1,4-di- $N$-oxide derivatives was carried out on the epimastigote form of $T$. cruzi. The selection of the epimastigote form of $T$. cruzi as an obligate mammalian intracellular stage has been re-evaluated and confirmed [37-39]. The results obtained are shown in table 2 . The strain used was Tulahuen 2 . The ability of each compound 
(dose $25 \mu \mathrm{M}$ ) to inhibit the growth of the parasite (PGI) was evaluated and compared to the control (no drug added to the media) on day 5. For compounds showing high values of PGI, the $50 \%$ inhibitory growth concentrations $\left(\mathrm{IC}_{50}\right)$, were evaluated. In both assays, Nifurtimox $(\mathrm{Nfx})$ was used as the reference drug. The PGI and the $\mathrm{IC}_{50}$ were calculated as indicated in the Experimental Section. Table 2 shows the PGI and $\mathrm{IC}_{50}$ results obtained for the 18 newly synthesized derivatives and the values for the reference drug, Nfx. The new derivatives showed potent in vitro activity against the Tulahuen 2 strain of $T$. cruzi: all of them presenting PGI values higher than $85 \%$. Fourteen out of 18 compounds presented PGI values of $100 \%$ and sixteen out of 18 were more potent than the reference drug Nfx. Compound $\mathbf{1 7}$ was identified as the most active, showing an $\mathrm{IC}_{50}$ value of $0.4 \mu \mathrm{M}, 18$ times more active than $\mathrm{Nfx}(7.7 \mu \mathrm{M})$.

The results obtained permitted us to establish a series of structure-activity relationships with regard to the idealness of the substituents used in positions C-2, C-3, C-6 and C-7 of the quinoxaline ring. In addition, there is a clearly observed relationship between the electronic characteristics of substituents in the C-6 and/or C-7 of the quinoxaline ring and the in vitro biological activity obtained. As shown in Table 2, when substituents in C-6 and/or C-7

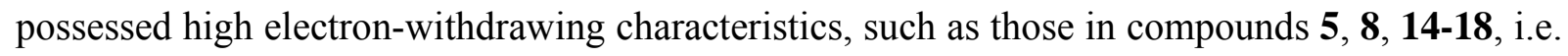
by chlorine, fluorine and trifluoromethyl, the biological activity increased, resulting in lower $\mathrm{IC}_{50}$ values. However, when substituents in C-6 and/or C-7 had electron-releasing character, such as the $\mathrm{CH}_{3}$ group in compounds $\mathbf{3}$ and $\mathbf{1 3}$, the activity decreased.

Within each series of compounds (1-9 and 10-18), the best results were obtained from the derivatives substituted by fluorine in C-6 and C-7 of the quinoxaline ring (compounds 8 and 17). 
In order to carry out a study on the structure-activity relationships with respect to the substituents used in C-2 and C-3, Table 5 has been included in the supporting information. This Table 5 shows the in vitro activity results of 19 quinoxaline 1,4-di- $N$-oxide derivatives, previously evaluated by our research group [27]. With respect to position C-3 of the quinoxaline ring, the introduction of the trifluoromethyl group is decisive in the in vitro biological activity shown by the derivatives with with-drawing substituents in C-6 and C-7; this is clearly observed upon comparing the activity of the new derivatives with the activity shown by the analogs with a methyl group or phenyl group in C-3 (A,L vs 13, E vs 1, D vs 4, O vs 11 and N vs 12, Tables 2 and 5). However, this influence appears not to be as great in the derivatives substituted by chlorine, and especially by fluorine, in C-6 and C-7. We observed this in the results obtained from the analog compounds $\mathrm{J}, \mathrm{P}$ and $\mathrm{R}$, which show very good biological activity against $T$. cruzi and in C-3 they present methyl or phenyl, respectively. These data appear to indicate that the influence of the trifluoromethyl group on the activity depends on the electronic character of the substituents used in C-6 and C-7 of the quinoxaline ring.

A similar explanation could be given for the rationale involved in the replacement of the ketone at C-2 [27] of quinoxaline ring by a methyl or an ethyl ester. The ester derivatives improve the biological activity of the corresponding ketone in every case with the exception of when the substituents in C-3, C-6 and C-7 are $\mathrm{CF}_{3}, \mathrm{~F}$ and $\mathrm{F}$ respectively.

Finally, with regard to the C-2 substituent, the influence of a methyl or ethyl group in determining the biological activity is not clear. Comparing the activity of the two series of new derivatives presented in our work (1-9 vs. 10-18), the presence of the ethyl ester group (compounds 10-18) slightly improves the in vitro activity results shown by the derivatives that possess the methyl ester group (compounds 1-9) with the exception of the derivatives without 
substitutions (1 vs. 10) and in those that are substituted with $\mathrm{CH}_{3}$ at $\mathrm{C}-6$ and $\mathrm{C}-7$ of the quinoxaline ring (4 vs. 13).

As our group had observed in previous works that we had carried out [27], it can be confirmed that the most decisive structural characteristic, in terms of in vitro biological activity, is the presence of substituents with an with-drawing character in positions 3, 6 and 7 of the quinoxaline ring, especially fluorine atoms. It is well-known that the introduction of fluorine atoms can modify the electronic, lipophilic and pharmacokinetic properties of drugs considerably. [40-42]

\section{Table 2}

\subsection{CYTOTOXICITY IN MAMMALIAN CELLS}

Due to the excellent in vitro activity data against $T$. cruzi obtained for the 18 new compounds we decided to explore their in vitro cytotoxicity in mammalian cells using the MTT assay. The $\mathrm{IC}_{50}$ values obtained and selective indexes (SI) calculated for 13 out of 18 new derivatives after $48 \mathrm{~h}$ of incubation are shown in Table 3. The selective indexes were calculated as the ratio of $\mathrm{IC}_{50}$ in macrophages to $\mathrm{IC}_{50}$ in $T$. cruzi Tulahuen 2 strain. Nfx data were previously reported. [43] As shown in Table 3, the newly synthesized compounds showed lower selectivity against the parasite than Nfx. The compounds $\mathbf{1}$ and $\mathbf{1 7}$ showed the highest selectivity against the parasite. In the conducted assay, cytotoxicity was determined from the function of mitochondrial dehydrogenases enzymes activity. Analogous compounds to those showed inhibitory capacity on these kinds of enzymes. [27] The significant effect observed on the cytotoxicity in the MTT assay could be related to mitochondrial dehydrogenases inhibitory activity.

\section{Table 3}




\subsection{AMES TEST: MUTAGENICITY}

The results obtained from the Ames test in S. typhimurium TA98 strain for compounds 1-18 with and without S9 activation are shown in Table 4. The evaluated doses of each compound were determined in previous solubility and toxicity studies on the test system. We observed that four of the eighteen tested derivatives $(\mathbf{6}, \mathbf{9}, \mathbf{1 5}$ and 18) were not mutagenic in any of the two conditions tested, with or without S9 activation. Compounds $\mathbf{6}$ and 9 belong to the methyl-ester series and $\mathbf{1 5}$ and $\mathbf{1 8}$ to the ethyl-ester series. All of these four compounds have electronwithdrawing substituents at C-6- and/or C-7 in the quinoxaline ring, with compounds 6 and 15 being the 6,7-diCl derivatives and compounds 9 and $\mathbf{1 8}$ being the $7-\mathrm{CF}_{3}$ derivatives.

The other derivatives with electron-withdrawing substituents and the unsubstituted derivatives (compounds 5, 7, 8, 10, 12, 13, 14, 16 and 17) showed mutagenicity in the assay without metabolic activation. However, this mutagenicity disappeared when the assay was performed with metabolic activation.

Derivatives 1-4 and 11, all possessing electron-releasing substituents $\left(\mathrm{CH}_{3} \mathrm{O}, \mathrm{CH}_{3}\right.$ and $\left.\operatorname{diCH}_{3}\right)$ at positions 6 and/or 7, exhibited mutagenicity in both conditions tested (-S9 and +S9).

Derivatives with electron-withdrawing groups at the 6- and/or 7-positions either showed no mutagenicity or the mutagenicity would disappear after the derivatives were metabolized. On the other hand, derivatives with electron-releasing substituents in these same positions showed high mutagenicity, especially derivative 2 , with a methoxy group at C-7. These results suggest a clear relationship between the mutagenicity observed in the Ames test and the electronic character of substituents at C-6- and/or C-7 of the quinoxaline ring. 


\section{Table 4}

\subsection{ELECTROCHEMISTRY}

The redox properties of 16 quinoxaline derivatives between -0.4 and $-2.6 \mathrm{~V}\left(\mathrm{vs} \mathrm{Ag} / \mathrm{AgNO}_{3}\right.$ ) were investigated using cyclic voltammetry in DMF with TBAP as supporting electrolyte. These compounds fall into two different categories: derivatives with a 3-methyl group (A, B and C) and derivatives with a 3-trifluoromethyl group (3-4, 6-12 and 14-17). All redox potentials are reported versus the ferrocene/ferrocinium $\left(\mathrm{Fc}_{\mathrm{Fc}}{ }^{+}\right)$redox couple. All voltammetric reductions were found to be diffusion controlled, as indicated by fairly constant current functions at the different scan rates used in the study. [44, 45]

The electrochemical reductions of various quinoxaline di- $N$-oxide derivatives in aprotic solvent systems have been reported previously. [46-52]. In the current study, several voltammetric waves were observed during cyclic voltammetry of the quinoxaline di- $N$-oxide derivatives between -0.4 and $-2.3 \mathrm{~V}$. The first reduction process observed in the voltammograms may be attributed to reduction of the nitrone functionality, forming a radical anion (Figure 1). [46-52]

\section{Figure 1}

The influence of structure on reduction potential may be examined by comparison of the data found in Table 2. Substitution of an electron withdrawing group onto the quinoxaline ring at positions C-3 or C-7 causes a positive shift in reduction potential, making reduction more facile. For example, replacing the 7-hydrogen atom in compound $\mathbf{1}$ with the 7-fluoro group in compound 7 and the 7-trifluoromethyl group in compound 9 resulted in shifts in $E_{1 / 2}$ of $+0.102 \mathrm{~V}$ and $+0.232 \mathrm{~V}$, respectively. Likewise, replacing the 3-methyl group in compound $\mathbf{C}$ with the 3- 
trifluoromethyl group in compounds $\mathbf{6}$ and $\mathbf{1 5}$ resulted in a positive shift in $\mathrm{E}_{1 / 2}$ of $+0.290 \mathrm{~V}$ and $+0.285 \mathrm{~V}$, respectively. Other examples may be observed by comparing compounds B vs. 12, and 10 vs. 14 vs. 16. In addition, substitution of a second electron-withdrawing group onto the quinoxaline ring at C-6 enhanced these effects (cf. 1 vs. 7 vs. 8, 10 vs. 14 vs. 15, 10 vs. 16 vs. 17).

Substitution of an electron donating group, i.e. methyl and methoxy, in these same positions on the quinoxaline ring causes a negative shift in reduction potential, i.e. reduction becomes more difficult. For example, replacing the 7-hydrogen atom in compound $\mathbf{1 0}$ with the 7-methyl group in derivative $\mathbf{1 2}$ and the 7-methoxy group in $\mathbf{1 1}$ resulted in shifts in $\mathrm{E}_{1 / 2}$ of $-0.043 \mathrm{~V}$ and -0.076 $\mathrm{V}$, respectively. The results of the present study agree with previous electrochemical studies dealing with the effects of structure on the reduction potentials of quinoxaline di- $N$-oxide derivatives, $[46-48,50-52]$ and indicate that reduction is facilitated by a positive charge at the reaction site. [53]

The influence of the substituent at $\mathrm{R}_{2}$, i.e. $-\mathrm{CO}_{2} \mathrm{Me}$ vs. $-\mathrm{CO}_{2} \mathrm{Et}$, on potential appeared to be negligible, in agreement with a previous study. [51]

The voltammetric results provide some pieces of information that may be important for understanding the mechanism of anti- $T$. cruzi activity for these compounds. The data suggest a possible relationship between ease of reduction and activity (Table 2). A plot of $E_{1 / 2}$ versus PGI $\%$ is shown in Chart 2. The chart shows that there is not a direct correlation between reduction potential and activity. However, examination of the data shows that the compounds with reduction potentials more negative than $-1.3 \mathrm{~V}$ tend to be generally less active. In fact, of the 
seven compounds with $\mathrm{E}_{1 / 2}$ values lower than $-1.3 \mathrm{~V}$, five exhibit activities below a PGI of $100 \%$

The quinoxalines 1,4 -di- $N$-oxide functionality could be activated through a bioreduction process which leads to the production of $\mathrm{OH}$ radicals or other oxy radical species and anionic active forms in the biological medium. If this is the case, bioreductive activation would generally be expected to be more facile for more easily reduced derivatives. In a previous study, we demonstrated that mitochondrial dehydrogenases are involved in the anti-T. cruzi activity of active quinoxaline-1,4-di- $N$-oxide-2-ketone derivatives, [27] indicating that redox behavior is important to the mechanism of action of the latter quinoxaline di- $N$-oxides. It is conceivable that a similar mechanism of action is involved with the quinoxaline 1,4-di- $N$-oxide-2-alkyl carboxylate derivatives. However, exceptions in the data, represented by derivatives $\mathbf{1 1}$ and 12, indicate that factors besides bioreduction must also be considered in the mechanism of anti- $T$. cruzi action, i.e. absorption, membrane permeability, metabolism, solubility, and site binding, just to name a few examples.

\section{Chart 2}

\section{CONCLUSIONS}

Eighteen new 1,4-di- $N$-oxide derivatives were synthesized using a variation of the Beirut reaction. A new synthetic method was optimized by microwave-assisted synthesis, providing an increase in reaction yields and a dramatic decline in the reaction times. The new derivatives showed high biological in vitro activity against $T$. cruzi, sixteen of which had greater in vitro efficacy against Tulahuen 2 strain than that of Nifurtimox. The importance of the presence of a trifluoromethyl group at the $\mathrm{C}-3$ of the quinoxaline ring in the in vitro biological activity was 
confirmed. Introduction of electron-withdrawing substituents at C-6 and/or C-7 of the quinoxaline ring enhanced in vitro biological activity against $T$. cruzi. In addition, this led to the obtainment of non-mutagenic derivatives in both the Ames assays that were performed or their mutagenicity disappeared when performing the assay using metabolic activation. In general, the selectivity shown by the new derivatives against the parasite could be improved. However, due to the inhibition exerted on mitochondrial dehydrogenases by related compounds and the characteristics of the MTT trial used, this issue will be discussed in depth in future trials.

Furthermore, it was found that the presence of electron-withdrawing substituents facilitated the reduction process of the $N$-oxides: and compounds with less negative values of reduction potential generally showed greater efficacy against the parasite. These results suggested that a bioreduction process of the $N$-oxides might be taking place in the mechanism of action of these types of derivatives. Compound $\mathbf{1 7}$ was identified as the most active and showed the highest selectivity against the parasite. In addition, it was not mutagenic in the Ames test conducted with metabolic activation.

The information obtained will be useful for the design of future derivatives with greater biological activities against $T$. cruzi and better toxicity profiles.

\section{EXPERIMENTAL SECTION}

\subsection{SYNTHESIS}

All of the synthesized compounds were chemically characterized by melting point, thin layer chromatography (TLC), infrared spectroscopy (IR), proton nuclear magnetic resonance $\left({ }^{1} \mathrm{H}\right.$ NMR) and elemental microanalyses (CHN). 
Melting points were determined with a Mettler FP82+FP80 apparatus (Greifense, Switzerland) and have not been corrected. The IR spectra were recorded on a Nicolet Nexus FTIR (Thermo, Madison, USA) using $\mathrm{KBr}$ pellets. The ${ }^{1} \mathrm{H}$ NMR spectra were recorded on a Bruker 400 Ultrashield instrument (400 MHz), using TMS as the internal standard and with $\mathrm{CDCl}_{3}$ as the solvent; the chemical shifts are reported in ppm $(\delta)$ and coupling constant $(J)$ values are given in Hertz (Hz). Signal multiplicities are represented by: s (singlet), d (doublet), dd (double doublet), ddd (doublet of double doublet), $\mathrm{t}$ (triplet), $\mathrm{q}$ (quadruplet) and $\mathrm{m}$ (multiplet). Elemental microanalyses were obtained on a CHN-900 Elemental Analyzer (Leco, Tres Cantos, Spain) from vacuum-dried samples. The analytical results for $\mathrm{C}, \mathrm{H}$ and $\mathrm{N}$, were within 0.4 of the theoretical values.

Microwave-assisted synthesis was carried out with a Discover SP System reactor (CEM Corporation), using the Synergy ${ }^{\mathrm{TM}}$ software.

Alugram SIL G/UV254 (Layer: 0.2 mm) (Macherey-Nagel GmbH \& Co. KG., Düren, Germany) was used for TLC. Column chromatography was developed by Silica gel 60, with 0.040-0.063 mm particle size (Merck, Darmstadt, Alemania).

Chemicals were purchased from Panreac Química S.A. (Barcelona, Spain), Sigma-Aldrich Química, S.A. (Alcobendas, Spain), Acros Organics (Janssen Pharmaceuticalaan, Geel, Belgium) and Lancaster (Bischheim-Strasbourg, France).

\subsubsection{General procedure of the synthesis of 2-alkylcarbonyl-3-trifluoromethylquinoxaline-} 1,4-di- $N$-oxide derivatives using $\mathrm{K}_{2} \mathrm{CO}_{3}$ (METHOD I). 
The corresponding BFX (10 mmol) was dissolved in acetone $(25 \mathrm{~mL})$ and then cooled by placing it on ice. Next, 4,4,4-trifluoroacetoacetate $(15 \mathrm{mmol})$ was added dropwise and $\mathrm{K}_{2} \mathrm{CO}_{3}(20 \mathrm{mmol})$ was added as the base. The reaction mixture was stirred at room temperature for 1-7 days, depending on the BFX substituents that were used. The product formation was checked out using TLC. Then the solvent was evaporated under reduced pressure. The obtained solid was dissolved in dichloromethane and washed with water in order to eliminate the catalyst salt. The organic phase was dried with anhydrous $\mathrm{K}_{2} \mathrm{SO}_{4}$ and then the solvent was evaporated under reduced pressure. The obtained oil was purified by column chromatography using dichloromethane as the eluent. The pure oil obtained was treated with diethyl ether and precipitated as a yellow solid.

\subsubsection{General procedure of the synthesis of 2-alkylcarbonyl-3-trifluoromethylquinoxaline-}

\section{1,4-di- $N$-oxide-derivatives using microwave-assisted method (METHOD II).}

The appropriate BFX (10 mmol) was dissolved in $15 \mathrm{~mL}$ of toluene in a microwave vessel (35 $\mathrm{mL})$. The mixture was cooled with ice. Next, 4,4,4-trifluoroacetoacetate (15 mmol) was added dropwise and finally $\mathrm{Et}_{3} \mathrm{~N}(1.5 \mathrm{~mL})$ was added dropwise as the base. The mixture reaction was inserted in the microwave reactor and then subjected to an optimized method: microwave irradiation at $60 \mathrm{~W}$ for $40-60$ minutes, depending on the BFX substituents used, keeping the temperature at $70{ }^{\circ} \mathrm{C}$. Once the reaction time finished, formation of the product was observed by TLC. The solvent was then eliminated under reduced pressure. Brown oil was obtained and it was purified by column chromatography, using dichloromethane as eluent. The obtained pure oil was precipitated with diethyl ether and then filtered off.

\subsubsection{2- Methoxycarbonyl-3-trifluoromethylquinoxaline-1,4-di- $N$-oxide (1)}


Yield: 3\%. IR (KBr): 3108 (w, vC-H Ar), 1748 (s, vC=O), 1364 (s, vN-oxide), 1163 (m, vC-F).

${ }^{1} \mathrm{H}$ NMR (400 MHz, $\left.\mathrm{CDCl}_{3}\right) \delta$ ppm: 8.63-8.57 (m, 2H, $\left.\mathrm{H}_{5}+\mathrm{H}_{8}\right) ;$ 7.97-8.04 (m, 2H, $\left.\mathrm{H}_{6}+\mathrm{H}_{7}\right)$; $4.12\left(\mathrm{~s}, 3 \mathrm{H}, \mathrm{CH}_{3}\right.$ ). Calc. Anal. for $\mathrm{C}_{11} \mathrm{H}_{7} \mathrm{~F}_{3} \mathrm{~N}_{2} \mathrm{O}_{4}$ : C, 45.85\%; H, 2.45\%; N, 9.72\%. Found: C, $45.98 \% ; \mathrm{H}, 2.34 \%$; N, $9.55 \%$.

\subsubsection{7-Methoxy-2-methoxycarbonyl-3-trifluoromethylquinoxaline-1,4-di- $N$-oxide (2)}

Yield: 4\%. IR (KBr): 3089 (w, vC-H Ar), 1739 (s, vC=O), 1354 (s, vN-oxide), 1261 (m, vC-O), 1145 (m, vC-F). ${ }^{1} \mathrm{H}$ NMR (400 MHz, $\left.\mathrm{CDCl}_{3}\right) \delta$ ppm: 8.54 (d, 1H, $\left.\mathrm{H}_{5}, J_{5-6}=9.3 \mathrm{~Hz}\right) ; 7.88(\mathrm{~d}, 1 \mathrm{H}$, $\left.\mathrm{H}_{8}, J_{8-6}=2.3 \mathrm{~Hz}\right) ; 7.54\left(\mathrm{dd}, 1 \mathrm{H}, \mathrm{H}_{6}, J_{6-8}=2.6 \mathrm{~Hz}, J_{6-5}=9.3 \mathrm{~Hz}\right) ; 4.11\left(\mathrm{~d}, 3 \mathrm{H}, \mathrm{CH}_{3}, J_{C H 3-C F 3}=1.5\right.$ $\mathrm{Hz}) ; 4.06$ (s, 3H, $\mathrm{CH}_{3} \mathrm{O}$ ). Calc. Anal. for $\mathrm{C}_{12} \mathrm{H}_{9} \mathrm{~F}_{3} \mathrm{~N}_{2} \mathrm{O}_{5}$ : C, 45.28\%; H, 2.83\%; N, 8.80\%. Found: C, $45.18 \% ; \mathrm{H}, 2.90 \% ; \mathrm{N}, 8.86 \%$.

\subsubsection{2-Methoxycarbonyl-7-methyl-3-trifluoromethylquinoxaline-1,4-di- $N$-oxide (3)}

Traditional yield: 8\%. IR (KBr): 3105 (w, vC-H Ar), 1735 (s, vC=O), 1355 (s, vN-oxide), 1274 (m, vC-O), $1152(\mathrm{~m}, v \mathrm{C}-\mathrm{F}) .{ }^{1} \mathrm{H}$ NMR (400 MHz, $\left.\mathrm{CDCl}_{3}\right) \delta \mathrm{ppm}: 8.54\left(\mathrm{~d}, 1 \mathrm{H}, \mathrm{H}_{5}, J_{5-6}=8.6 \mathrm{~Hz}\right)$; $8.40\left(\mathrm{~s}, 1 \mathrm{H}, \mathrm{H}_{8}\right) ; 7.79\left(\mathrm{~d}, 1 \mathrm{H}, \mathrm{H}_{6}, J_{6-5}=8.6 \mathrm{~Hz}\right) ; 4.10\left(\mathrm{~s}, 3 \mathrm{H}, \mathrm{CH}_{3}\right) ; 2.67$ (s, 3H, $\left.\mathrm{CH}_{3}-\mathrm{C}_{7}\right)$. Calc. Anal. for $\mathrm{C}_{12} \mathrm{H}_{9} \mathrm{~F}_{3} \mathrm{~N}_{2} \mathrm{O}_{4}$ : C, 47.69\%; H, 3.00\%; N, 9.27\%. Found: C, 47.49\%; H, 3.07\%; N, $9.13 \%$.

\subsubsection{2-Methoxycarbonyl-6,7-dimethyl-3-trifluoromethylquinoxaline-1,4-di- $N$-oxide (4)}

Traditional yield: 4\%. IR (KBr): 3090 (w, vC-H Ar), 1756 (s, vC=O), 1343 (s, vN-oxide), 1268

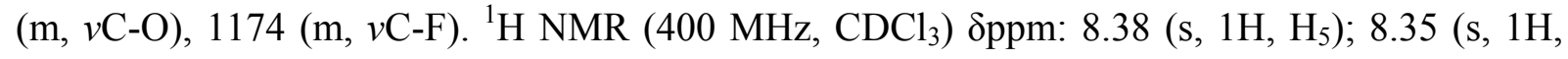
$\left.\mathrm{H}_{8}\right) ; 4.10\left(\mathrm{~s}, 3 \mathrm{H}, \mathrm{CH}_{3}\right) ; 2.57\left(\mathrm{~s}, 6 \mathrm{H}, \mathrm{CH}_{3}-\mathrm{C}_{6}+\mathrm{CH}_{3}-\mathrm{C}_{7}\right)$. Calc. Anal. for $\mathrm{C}_{13} \mathrm{H}_{11} \mathrm{~F}_{3} \mathrm{~N}_{2} \mathrm{O}_{4}: \mathrm{C}$, $49.38 \%$; H, 3.51\%; N, 8.86\%. Found: C, 48.99\%; H, 3.20\%; N, 8.17\%. 


\subsubsection{7-Chloro-2-methoxycarbonyl-3-trifluoromethylquinoxaline-1,4-di- $\mathrm{N}$-oxide (5)}

Yield: $22 \%$. IR (KBr): (w, $v \mathrm{C}-\mathrm{H}$ Ar), $(\mathrm{s}, v \mathrm{C}=\mathrm{O}),(\mathrm{s}, v N$-oxide $),(\mathrm{m}, v \mathrm{C}-\mathrm{O}),(\mathrm{m}, v \mathrm{C}-\mathrm{F}) .{ }^{1} \mathrm{H}$ NMR $\left(400 \mathrm{MHz}, \mathrm{CDCl}_{3}\right) \delta$ ppm: $8.58\left(\mathrm{~d}, 1 \mathrm{H}, \mathrm{H}_{5}, J_{5-6}=9.0 \mathrm{~Hz}\right) ; 8.58\left(\mathrm{~d}, 1 \mathrm{H}, \mathrm{H}_{8}, J_{8-6}=2.0 \mathrm{~Hz}\right) ; 7.90$ $\left(\mathrm{dd}, 1 \mathrm{H}, \mathrm{H}_{6}, J_{6-5}=9.3 \mathrm{~Hz}, J_{6-8}=2.0 \mathrm{~Hz}\right) ; 4.0\left(\mathrm{~d}, 3 \mathrm{H}, \mathrm{CH}_{3}, J_{C H 3-C F 3}=1.5 \mathrm{~Hz}\right)$. Calc. Anal. for $\mathrm{C}_{11} \mathrm{H}_{6} \mathrm{~F}_{3} \mathrm{~N}_{2} \mathrm{O}_{4} \mathrm{Cl}: \mathrm{C}, 40.95 \% ; \mathrm{H}, 1.87 \%$; N, 8,68\%. Found: C, 41.03\%; H, 1.88\%; N, 8.58\%.

\subsubsection{6,7-Dichloro-2-methoxycarbonyl-3-trifluoromethylquinoxaline-1,4-di- $\mathrm{N}$-oxide (6)}

Yield: 4\%. IR (KBr): 3177 (w, vC-H Ar), 1756 (s, vC=O), 1339 (s, vN-oxide), 1278 (m, $v \mathrm{C}-\mathrm{O})$, 1169 (m, vC-F). ${ }^{1} \mathrm{H}$ NMR (400 MHz, $\mathrm{CDCl}_{3}$ ) $\delta$ ppm: 8.74 (s, 1H, $\mathrm{H}_{5}$ ); 8.71 (s, 1H, $\mathrm{H}_{8}$ ); 4.10 (s, $3 \mathrm{H}, \mathrm{CH}_{3}$ ). Calc. Anal. for $\mathrm{C}_{11} \mathrm{H}_{5} \mathrm{Cl}_{2} \mathrm{~F}_{3} \mathrm{~N}_{2} \mathrm{O}_{4}$ : C, 36.97\%; H, 1.4\%; N, 7.84\%. Found: $\mathrm{C}, 36.66 \%$; $\mathrm{H}, 1.38 \%$; N, $7.72 \%$.

\subsubsection{7-Fluoro-2-methoxycarbonyl-3-trifluoromethylquinoxaline-1,4-di- $N$-oxide (7)}

Yield: 25\%. IR (KBr): 3077 (w, $v \mathrm{C}-\mathrm{H}$ Ar), 1756 (s, vC=O), 1340 (s, vN-oxide), 1278 (m, $v \mathrm{C}-\mathrm{O})$,

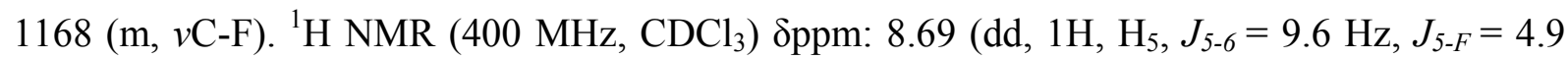
$\mathrm{Hz}) ; 8.28\left(\mathrm{dd}, 1 \mathrm{H}, \mathrm{H}_{8}, J_{8-F}=8.0 \mathrm{~Hz}, J_{8-6}=2.7 \mathrm{~Hz}\right) ; 7.72\left(\mathrm{ddd}, 1 \mathrm{H}, \mathrm{H}_{6}, J_{6-5}=9.7 \mathrm{~Hz}, J_{6-F}=7.2\right.$ $\left.\mathrm{Hz}, J_{6-8}=2.7 \mathrm{~Hz}\right) ; 4.12\left(\mathrm{~s}, 3 \mathrm{H}, \mathrm{CH}_{3}\right)$. Calc. Anal. for $\mathrm{C}_{11} \mathrm{H}_{6} \mathrm{~F}_{4} \mathrm{~N}_{2} \mathrm{O}_{4}: \mathrm{C}, 43.15 \% ; \mathrm{H}, 1.98 \%$; N, 9.15\%. Found: C, $43.18 \% ; \mathrm{H}, 1.84 \% ; \mathrm{N}, 8.85 \%$.

\subsubsection{6,7-Difluoro-2-methoxycarbonyl-3-trifluoromethylquinoxaline-1,4-di- $N$-oxide (8)}

Yield: 4\%. IR (KBr): $3066(\mathrm{w}, v \mathrm{C}-\mathrm{H}$ Ar), $1750(\mathrm{~s}, v \mathrm{C}=\mathrm{O}), 1356$ (s, vN-oxide), 1252 (m, $v \mathrm{C}-\mathrm{O})$,

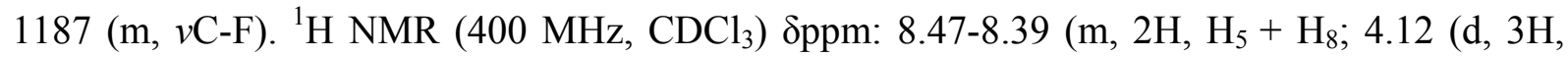


$\mathrm{CH}_{3}$ ). Calc. Anal. for $\mathrm{C}_{11} \mathrm{H}_{5} \mathrm{~F}_{5} \mathrm{~N}_{2} \mathrm{O}_{4}: \mathrm{C}, 40.70 \% ; \mathrm{H}, 1.55 \%$; N, 8.64\%. Found: $\mathrm{C}, 40.79 \%$; $\mathrm{H}$, $1.35 \% ; \mathrm{N}, 8.54 \%$.

\subsubsection{2-Methoxycarbonyl-3,7-bis (trifluoromethyl) quinoxaline-1,4-di- $N$-oxide (9)}

Yield: 2\%. IR (KBr): 3108 (w, vC-H Ar), 1755 (s, vC=O), 1351 (s, vN-oxide), 1267 (m, vC-O), $1170(\mathrm{~m}, v \mathrm{C}-\mathrm{F}) .{ }^{1} \mathrm{H}$ NMR $\left(400 \mathrm{MHz}, \mathrm{CDCl}_{3}\right) \delta(\mathrm{ppm}): 8.92\left(\mathrm{~d}, 1 \mathrm{H}, \mathrm{H}_{8}, J_{8-6}=1.8 \mathrm{~Hz}\right) ; 8.80(\mathrm{~d}$, $\left.1 \mathrm{H}, \mathrm{H}_{5}, J_{5-6}=9.0 \mathrm{~Hz}\right) ; 8.18\left(\mathrm{dd}, 1 \mathrm{H}, \mathrm{H}_{6}, J_{6-5}=9.0 \mathrm{~Hz}, J_{6-8}=1.7 \mathrm{~Hz}\right) ; 4.12\left(\mathrm{~s}, 3 \mathrm{H}, \mathrm{CH}_{3}\right)$. Calc. Anal. for $\mathrm{C}_{12} \mathrm{H}_{6} \mathrm{~F}_{6} \mathrm{~N}_{2} \mathrm{O}_{4}: \mathrm{C}, 40.45 \% ; \mathrm{H}, 1.68 \% ; \mathrm{N}, 7.86 \%$. Found: $\mathrm{C}, 40.82 \% ; \mathrm{H}, 1.75 \%$; , $7.73 \%$.

\subsubsection{2-Ethoxycarbonyl-3-trifluoromethylquinoxaline-1,4-di- $N$-oxide (10)}

Yield: 1\%. Microwave yield: 8\%. IR (KBr): $3016(\mathrm{w}, v \mathrm{C}-\mathrm{H}$ Ar), $1744(\mathrm{~s}, v \mathrm{C}=\mathrm{O}), 1360$ (s, vNoxide), 1264 (m, vC-O), 1154 (m, vC-F). ${ }^{1} \mathrm{H}$ NMR (400 MHz, $\left.\mathrm{CDCl}_{3}\right)$ 8ppm: 8.66-8.62 (m, 2H, $\left.\mathrm{H}_{5}+\mathrm{H}_{8}\right) ; 7.97-8.03\left(\mathrm{~m}, 2 \mathrm{H}, \mathrm{H}_{6}+\mathrm{H}_{7}\right) ; 4.59\left(\mathrm{q}, 2 \mathrm{H}, \mathrm{CH}_{2}, J_{\mathrm{CH} 2-\mathrm{CH} 3}=7.1 \mathrm{~Hz}\right) ; 1.47\left(\mathrm{t}, 3 \mathrm{H}, \mathrm{CH}_{3}\right.$, $J_{C H 3-C H 2}=7.1 \mathrm{~Hz}$ ). Calc. Anal. for $\mathrm{C}_{12} \mathrm{H}_{9} \mathrm{~F}_{3} \mathrm{~N}_{2} \mathrm{O}_{4}: \mathrm{C}, 47.69 \% ; \mathrm{H}, 3.00 \%$; N, 9.27\%. Found: C, $47.49 \% ; \mathrm{H}, 3.07 \%$; N, 9.13\%.

\subsubsection{2-Ethoxycarbonyl-7-methoxy-3-trifluoromethylquinoxaline-1,4-di- $N$-oxide (11)}

Yield: 1\%. Microwave yield: 5\%. IR (KBr): $3087(\mathrm{w}, v \mathrm{C}-\mathrm{H}$ Ar), $1742(\mathrm{~s}, v \mathrm{C}=\mathrm{O}), 1356(\mathrm{~s}, v N-$ oxide), 1263 (m, vC-O), 1143 (m, vC-F). ${ }^{1} \mathrm{H}$ NMR (400 MHz, $\left.\mathrm{CDCl}_{3}\right) \delta \mathrm{ppm}: 8.54$ (d, 1H, $\mathrm{H}_{5}, J_{5-}$ $\left.{ }_{6}=9.5 \mathrm{~Hz}\right) ; 7.89\left(\mathrm{~d}, 1 \mathrm{H}, \mathrm{H}_{8}, J_{8-6}=2.6 \mathrm{~Hz}\right) ; 7.53\left(\mathrm{dd}, 1 \mathrm{H}, \mathrm{H}_{6}, J_{6-8}=2.7 \mathrm{~Hz}, J_{6-5}=9.5 \mathrm{~Hz}\right) ; 4.59(\mathrm{q}$, $\left.2 \mathrm{H}, \mathrm{CH}_{2}, J_{\mathrm{CH}_{2}-\mathrm{CH} 3}=7.1 \mathrm{~Hz}\right) ; 4.05\left(\mathrm{~s}, 3 \mathrm{H}, \mathrm{CH}_{3} \mathrm{O}\right) ; 1.47\left(\mathrm{t}, 3 \mathrm{H}, \mathrm{CH}_{3}, J_{\mathrm{CH}_{3} \mathrm{CH} 2}=7.1 \mathrm{~Hz}\right) . \mathrm{Calc}$. Anal. for $\mathrm{C}_{13} \mathrm{H}_{11} \mathrm{~F}_{3} \mathrm{~N}_{2} \mathrm{O}_{5}$ : C, 46,98\%; H, 3.31\%; N, 8.43\%. Found: C, 46.83\%; H, 3.24\%; N, $8.14 \%$. 


\subsubsection{2-Ethoxycarbonyl-7-methyl-3-trifluoromethylquinoxaline-1,4-di- $\mathrm{N}$-oxide (12)}

Yield: 1\%. Microwave yield: 4\%. IR (KBr): $3096(\mathrm{w}, v \mathrm{C}-\mathrm{H}$ Ar), $1743(\mathrm{~s}, v \mathrm{C}=\mathrm{O}), 1352$ (s, vNoxide), 1271 (m, vC-O), 1153 (m, vC-F). ${ }^{1} \mathrm{H}$ NMR (400 MHz, $\left.\mathrm{CDCl}_{3}\right) \delta p p m: ~ 8.53\left(\mathrm{~d}, 1 \mathrm{H}, \mathrm{H}_{5}, J_{5-}\right.$ $\left.{ }_{6}=8.8 \mathrm{~Hz}\right) ; 8.41\left(\mathrm{~s}, 1 \mathrm{H}, \mathrm{H}_{8}\right) ; 7.78\left(\mathrm{dd}, 1 \mathrm{H}, \mathrm{H}_{6}, J_{6-5}=8.9 \mathrm{~Hz}, J_{6-8}=1.4 \mathrm{~Hz}\right) ; 4.58\left(\mathrm{q}, 2 \mathrm{H}, \mathrm{CH}_{2}\right.$, $\left.J_{\mathrm{CH}_{2}-\mathrm{CH} 3}=7.1 \mathrm{~Hz}\right) ; 2.67\left(\mathrm{~s}, 3 \mathrm{H}, \mathrm{CH}_{3}\right) ; 1.47\left(\mathrm{t}, 3 \mathrm{H}, \mathrm{CH}_{3}, J_{\mathrm{CH} 3-\mathrm{CH} 2}=7.1 \mathrm{~Hz}\right)$. Calc. Anal. for $\mathrm{C}_{13} \mathrm{H}_{10} \mathrm{~F}_{3} \mathrm{~N}_{2} \mathrm{O}_{4}$ : C, 49,36\%; H, 3.48\%; N, 8.86\%. Found: C, 49.22\%; H, 3.38\%; N, 8.79\%.

\subsubsection{2-Ethoxycarbonyl-6,7-dimethyl-3-trifluoromethylquinoxaline-1,4-di- $N$-oxide (13)}

Yield: 1\%. IR (KBr): 3068 (w, vC-H Ar), 1749 (s, vC=O), 1356 (s, vN-oxide), 1270 (m, vC-O),

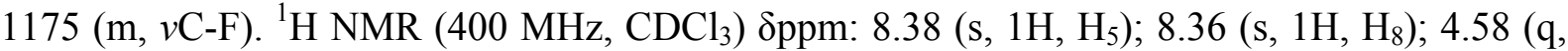
$\left.2 \mathrm{H}, \mathrm{CH}_{2}, J_{\mathrm{CH}_{2}-\mathrm{CH} 3}=7.1 \mathrm{~Hz}\right) ; 2.57\left(\mathrm{~s}, 6 \mathrm{H}, \mathrm{CH}_{3}-\mathrm{C}_{6}+\mathrm{CH}_{3}-\mathrm{C}_{7}\right) ; 1.47\left(\mathrm{t}, 3 \mathrm{H}, \mathrm{CH}_{3}, J_{\mathrm{CH}_{3}-\mathrm{CH} 2}=7.1\right.$ Hz). Calc. Anal. for $\mathrm{C}_{14} \mathrm{H}_{13} \mathrm{~F}_{3} \mathrm{~N}_{2} \mathrm{O}_{4}:$ C, 50.90\%; H, 3.93\%; N, 8.48\%. Found: C, 51.09\%; H, $3.91 \% ; \mathrm{N}, 8.24 \%$.

\subsubsection{7-Chloro-2-ethoxycarbonyl-3-trifluoromethylquinoxaline-1,4-di- $N$-oxide (14)}

Yield: 8\%. IR (KBr): 3071 (w, vC-H Ar), 1749 (s, vC=O), 1355 (s, vN-oxide), 1267 (m, $v \mathrm{C}-\mathrm{O})$, $1161(\mathrm{~m}, v \mathrm{C}-\mathrm{F}) .{ }^{1} \mathrm{H}$ NMR $\left(400 \mathrm{MHz}, \mathrm{CDCl}_{3}\right) \delta(\mathrm{ppm}): 8.61\left(\mathrm{~d}, 1 \mathrm{H}, \mathrm{H}_{8}, J_{8-6}=2.1 \mathrm{~Hz}\right) ; 8.59(\mathrm{~d}$, $\left.1 \mathrm{H}, \mathrm{H}_{5}, J_{5-6}=9.2 \mathrm{~Hz}\right) ; 7.90\left(\mathrm{dd}, 1 \mathrm{H}, \mathrm{H}_{6}, J_{6-5}=9.2 \mathrm{~Hz}, J_{6-8}=2.1 \mathrm{~Hz}\right) ; 4.59\left(\mathrm{q}, 2 \mathrm{H}, \mathrm{CH}_{2}, J_{\mathrm{CH}_{2}-\mathrm{CH} 3}=\right.$ $7.1 \mathrm{~Hz}$ ); 1.47 (t, 3H, $\mathrm{CH}_{3}, J_{C H 3-C H 2}=7.1 \mathrm{~Hz}$ ). Calc. Anal. for $\mathrm{C}_{12} \mathrm{H}_{8} \mathrm{ClF}_{3} \mathrm{~N}_{2} \mathrm{O}_{4}: \mathrm{C}, 42.79 \%$; $2.37 \%$; N, 8.32\%. Found: C, 42.61\%; H, 2.28\%; N, 8.20\%. 
Yield: 3\%. Microwave yield: 31\%. IR (KBr): 3081 (w, vC-H Ar), 1755 (s, vC=O), 1342 (s, vNoxide), 1269 (m, vC-O), 1171 (m, vC-F), 1022 (w, var-Cl) $\cdot{ }^{1} \mathrm{H}$ NMR $\left(400 \mathrm{MHz}, \mathrm{CDCl}_{3}\right) \delta$ (ppm): $8.74\left(\mathrm{~s}, 1 \mathrm{H}, \mathrm{H}_{5}\right) ; 8.72\left(\mathrm{~s}, 1 \mathrm{H}, \mathrm{H}_{8}\right) ; 4.58\left(\mathrm{q}, 2 \mathrm{H}, \mathrm{CH}_{2}, J_{\mathrm{CH} 2-\mathrm{CH} 3}=7.1 \mathrm{~Hz}\right) ; 1.46\left(\mathrm{t}, 3 \mathrm{H}, \mathrm{CH}_{3}\right.$, $J_{C H 3-C H 2}=7.1 \mathrm{~Hz}$ ). Calc. Anal. for $\mathrm{C}_{12} \mathrm{H}_{7} \mathrm{Cl}_{2} \mathrm{~F}_{3} \mathrm{~N}_{2} \mathrm{O}_{4}: \mathrm{C}, 38.81 \% ; \mathrm{H}, 1.88 \%$; N, 7.54\%. Found: C, $38.67 \% ; \mathrm{H}, 1.87 \% ; \mathrm{N}, 7.39 \%$.

\subsubsection{2-Ethoxycarbonyl-7-fluoro-3-trifluoromethylquinoxaline-1,4-di- $N$-oxide (16)}

Yield: 1\%. Microwave yield: 22\%. IR (KBr): 3119 (w, vC-H Ar), 1750 (s, vC=O), 1359 (s, vNoxide), 1267 (m, vC-O), 1171 (m, $v \mathrm{C}-\mathrm{F}) .{ }^{1} \mathrm{H}$ NMR (400 MHz, $\left.\mathrm{CDCl}_{3}\right) \delta(\mathrm{ppm}): 8.69$ (dd, 1H, $\mathrm{H}_{5}$, $\left.J_{5-6}=9.4 \mathrm{~Hz}, J_{5-F}=4.8 \mathrm{~Hz}\right) ; 8.28\left(\mathrm{dd}, 1 \mathrm{H}, \mathrm{H}_{8}, J_{8-F}=8.0 \mathrm{~Hz}, J_{8-6}=2.6 \mathrm{~Hz}\right) ; 7.72\left(\mathrm{ddd}, 1 \mathrm{H}, \mathrm{H}_{6}, J_{6-F}\right.$

$\left.=7.2 \mathrm{~Hz}, J_{6-8}=2.6 \mathrm{~Hz}\right) ; 4.59\left(\mathrm{q}, 2 \mathrm{H}, \mathrm{CH}_{2}, J_{\mathrm{CH} 2-\mathrm{CH} 3}=7.1 \mathrm{~Hz}\right) ; 1.47\left(\mathrm{t}, 3 \mathrm{H}, \mathrm{CH}_{3}, J_{\mathrm{CH}_{3}-\mathrm{CH}_{2}}=7.1\right.$ Hz). Calc. Anal. for $\mathrm{C}_{12} \mathrm{H}_{8} \mathrm{~F}_{4} \mathrm{~N}_{2} \mathrm{O}_{4}: \mathrm{C}, 45.00 \%$; H, 2.50\%; N, 8.75\%. Found: $\mathrm{C}, 45.00 \%$; $\mathrm{H}$, $2.41 \% ; \mathrm{N}, 8.63 \%$.

\subsubsection{2-Ethoxycarbonyl-6,7-difluoro-3-trifluoromethylquinoxaline-1,4-di- $N$-oxide (17)}

Yield: 10\%. IR (KBr): 3048 (w, $v \mathrm{C}-\mathrm{H}$ Ar), 1745 (s, vC=O), 1354 (s, vN-oxide), 1253 (m, vC-O), $1182(\mathrm{~m}, v \mathrm{C}-\mathrm{F}) .{ }^{1} \mathrm{H}$ NMR $\left(400 \mathrm{MHz}, \mathrm{CDCl}_{3}\right) \delta(\mathrm{ppm}): 8.46\left(\mathrm{dd}, 1 \mathrm{H}, \mathrm{H} 5, J_{5-F 6}=6.3 \mathrm{~Hz}, J_{5-F 7}=\right.$ $4.3 \mathrm{~Hz}$ ); $8.43\left(\mathrm{dd}, 1 \mathrm{H}, \mathrm{H} 8, J_{8-\mathrm{F} 7}=6.4 \mathrm{~Hz}, J_{8-\mathrm{F} G}=4.3 \mathrm{~Hz}\right) ; 4.58\left(\mathrm{q}, 2 \mathrm{H}, \mathrm{CH}_{2}, J_{\mathrm{CH}_{2}-\mathrm{CH} 3}=7.1 \mathrm{~Hz}\right)$; $1.47\left(\mathrm{t}, 3 \mathrm{H}, \mathrm{CH}_{3}, J_{\mathrm{CH} 3-\mathrm{CH} 2}=7.1 \mathrm{~Hz}\right.$ ). Calc. Anal. for $\mathrm{C}_{12} \mathrm{H}_{7} \mathrm{~F}_{5} \mathrm{~N}_{2} \mathrm{O}_{4}: \mathrm{C}, 42.60 \% ; \mathrm{H}, 2.07 \%$; , 8.28\%. Found: C, 42.59\%; H, 1.97\%; N, 8.16\%.

\subsubsection{2-Ethoxycarbonyl-3,7-bis (trifluoromethyl) quinoxaline-1,4-di- $N$-oxide (18)}

Yield: 2\%. IR (KBr): 3112 (w, vC-H Ar), 1750 (s, vC=O), 1350 (s, vN-oxide), 1268 (m, $v \mathrm{C}-\mathrm{O})$, 1159 (m, vC-F), 1118 (m, vC-F). ${ }^{1} \mathrm{H}$ NMR (400 MHz, $\left.\mathrm{CDCl}_{3}\right) \delta(\mathrm{ppm}): 8.93$ (s, 1H, $\left.\mathrm{H}_{8}\right) ; 8.79$ (d, 
$\left.1 \mathrm{H}, \mathrm{H}_{5}, J_{5-6}=9.0 \mathrm{~Hz}\right) ; 8.16\left(\mathrm{dd}, 1 \mathrm{H}, \mathrm{H}_{6}, J_{6-5}=9.0 \mathrm{~Hz}, J_{6-8}=1.4 \mathrm{~Hz}\right.$ ); $4.60\left(\mathrm{q}, 2 \mathrm{H}, \mathrm{CH}_{2}, J_{C H 2-C H 3}\right.$ $=7.1 \mathrm{~Hz}) ; 1.47\left(\mathrm{t}, 3 \mathrm{H}, \mathrm{CH}_{3}, J_{C H 3-C H 2}=7.1 \mathrm{~Hz}\right.$ ). Calc. Anal. for $\mathrm{C}_{13} \mathrm{H}_{8} \mathrm{~F}_{6} \mathrm{~N}_{2} \mathrm{O}_{4}: \mathrm{C}, 42.16 \% ; \mathrm{H}$, $2.16 \%$; N, 7.56\%. Found: C, 42.21\%; H, 1.96\%; N, 7.49\%.

\subsection{IN VITRO ANTI-T. CRUZI TULAHUEN 2 STRAIN ASSAY}

T. cruzi Tulahuen 2 strain epimastigotes were grown at $28{ }^{\circ} \mathrm{C}$ in an axenic medium (BHItryptose) as previously described, [19-21, 54-57] complemented with 5\% fetal bovine serum. Epimastigotes from a 10-day-old culture (stationary phase) were inoculated into $50 \mathrm{~mL}$ of fresh culture medium in order to give an initial concentration of $1 \times 10^{6}$ cells $/ \mathrm{mL}$. Cell growth was followed by measuring the absorbance of the culture at $600 \mathrm{~nm}$ every day. Before inoculation, the media was supplemented with a given amount of the drug from a stock solution in DMSO $(25 \mu \mathrm{M})$. The final concentration of DMSO in the culture medium never exceeded $0.4 \%$, and the control was run in the presence of $0.4 \%$ DMSO and in the absence of drugs.

The percentage of inhibition (PGI) was calculated as follows: PGI $(\%)=\{1-[(\mathrm{Ap}-\mathrm{A} 0 \mathrm{p}) /(\mathrm{Ac}-$ $\mathrm{A} 0 \mathrm{c})]\} \times 100$, where $\mathrm{Ap}=\mathrm{A}_{600}$ of the culture containing the drug on day $5, \mathrm{~A} 0 \mathrm{p}=\mathrm{A}_{600}$ of the culture containing the drug just after addition of the inocula (day 0), $A c=A_{600}$ of the culture in the absence of drugs (control) on day 5 , and $\mathrm{A} 0 \mathrm{c}=\mathrm{A}_{600}$ in the absence of the drug on day 0.

In order to determine $\mathrm{IC}_{50}$ values, $50 \%$ inhibitory concentrations, parasite growth was followed in the absence (control) and in the presence of a range of concentrations of the corresponding drug. On day 5 , the absorbance of the culture was measured and related to the control. The $\mathrm{IC}_{50}$ value was taken as the concentration of drug needed to reduce the absorbance ratio to $50 \%$.

\subsection{CYTOTOXICITY IN MAMMALIAN CELLS}


J-774 murine macrophage-like cells (ATCC, USA) were maintained by passage in Dulbecco's modified Eagle's medium (DMEM) containing $4 \mathrm{mM}$ L-glutamine, and supplemented with 10\% heatinactivated fetal calf serum and $1 \%$ of antibiotics $(10,000 \mathrm{U} / \mathrm{mL}$ penicillin and $10,000 \mathrm{lg} / \mathrm{mL}$ streptomycin). J-774 cells were seeded $\left(1 \times 10^{5}\right.$ cells/ well $)$ in 96 well microplates with $200 \mu \mathrm{L}$ of RPMI 1640 medium supplemented with $20 \%$ heat-inactivated fetal calf serum. Cells were allowed to attach for $48 \mathrm{~h}$ in a humidified $5 \% \mathrm{CO}_{2} / 95 \%$ air atmosphere at $37{ }^{\circ} \mathrm{C}$ and, then, exposed to compounds $(100.0-400.0 \mu \mathrm{M})$ for $48 \mathrm{~h}$. Afterwards, cell viability was assessed by measuring the mitochondrial-dependent reduction of MTT (Sigma) to formazan. For that purpose, MTT was added to cells to a final concentration $0.4 \mathrm{mg} / \mathrm{mL}$ and cells were incubated at $37{ }^{\circ} \mathrm{C}$ for $3 \mathrm{~h}$. After removing the media, formazan crystals were dissolved in DMSO $(180 \mu \mathrm{L})$, and the absorbance at $595 \mathrm{~nm}$ was read using a microplate spectrophotometer. Cytotoxicity percentages $(\% \mathrm{C})$ were determined as follows: $\% \mathrm{C}=\left[100-\left(\mathrm{OD}_{\mathrm{d}}-\mathrm{OD}_{\mathrm{dm}}\right) /\left(\mathrm{OD}_{\mathrm{c}}-\mathrm{OD}_{\mathrm{cm}}\right)\right] \mathrm{x} 100$, where $\mathrm{OD}_{\mathrm{d}}$ is the mean of $\mathrm{OD}_{595}$ of wells with macrophages and different concentrations of the compounds; $\mathrm{OD}_{\mathrm{dm}}$ is the mean of $\mathrm{OD}_{595}$ of wells with different compound concentrations in the medium; $\mathrm{OD}_{\mathrm{c}}$ is the growth control and $\mathrm{OD}_{\mathrm{cm}}$ is the mean of $\mathrm{OD}_{595}$ of wells with medium only. Results are expressed as $\mathrm{IC}_{50}$ (compound concentration that reduce $50 \%$ control absorbance at $595 \mathrm{~nm})$. Every $\mathrm{IC}_{50}$ is the average of three different experiments. The selectivity indexes, SI, were expressed as the ratio between $\mathrm{IC}_{50}$ in macrophages and $\mathrm{IC}_{50}$ in $T$. cruzi (Tulahuen 2 strain). $[58,59]$

\subsection{MUTAGENICITY ASSAY}

The preliminary Salmonella mutagenicity assay (Ames assay) was performed according to the method described earlier and following the OECD (Organisation for Economic Co-operation and Development) guideline 471 (Bacterial reverse mutation test) but only in S. typhimurium His, 
TA98 strain. [35, 60-62] Prior to starting the assay, the concentrations to be tested were selected in terms of solubility and toxicity results in the test system. For the mutagenicity test, a suspension of $2 \times 10^{9} S$. typhimurium $/ \mathrm{mL}$ was prepared and the treatment procedure with the different compounds was performed both with and without S9 mix as an external enzymatic metabolizing system. Rat liver S9, of commercial origin, was prepared as described earlier. [35] S9 fraction contains cytochrome P450 isoform enzymes, which are involved in drug metabolism and other enzyme activities. [63] In order to perform the assay without metabolic activation, the following was mixed in test tubes: $50 \mu \mathrm{L}$ of each test compound solution, $500 \mu \mathrm{L}$ of PBS $(0.1 \mathrm{M}$, $\mathrm{pH}$ 7.4) and $100 \mu \mathrm{L}$ of bacterial suspension. Once each compound was mixed, it was incubated for 1 hour at $37^{\circ} \mathrm{C}$ and then $2 \mathrm{~mL}$ of molten top agar supplemented with histidine and biotin traces $(0.05 \mathrm{mM}$ each) were added. The mixture was vortexed immediately and then poured onto glucose minimal (GM) agar plates.

The assay with metabolic activation was performed following the same procedure but replacing the $500 \mu \mathrm{L}$ of PBS by $500 \mu \mathrm{L}$ of S9 mix (10\%, v/v S9, $4.7 \mathrm{mM}$ NADP, $6 \mathrm{mM}$ d-glucose-6phosphate, $19 \mathrm{mM} \mathrm{MgCl}_{2}, 36 \mathrm{mM} \mathrm{KCl}$, phosphate buffer $0.1 \mathrm{M}, \mathrm{pH}$ 7.4).

When the top agar had solidified, the plates were incubated in an inverted position in an incubator at $37^{\circ} \mathrm{C}$ for $48 \mathrm{~h}$. After this time had elapsed, the histidine revertant colonies were counted.

The test always used a negative control (solvent control), in which the solvent (DMSO) was added without compound, giving us the basal spontaneous mutation rate and two positive controls, 4-O-nitrophenylendiamine (NPD) without metabolic activation and 2-aminofluorene (2-AF) with metabolic activation. In addition, a bacterial control was carried out in order to 
verify correct growing, and a phenotype control was carried out in order to assure that work was actually being carried out with the TA98 strain.

For all the assays, the data were analyzed using the modified 2-fold rule in which a response was considered to be positive if the average response for at least two consecutive dose levels was more than twice the spontaneous frequencies and a dose-response relationship is observed. [64]

\subsection{ELECTROCHEMICAL STUDIES}

Cyclic voltammetric measurements were performed with a CHI Instruments 630 Voltammetric Analyzer using scan rates ranging from $50 \mathrm{mV} / \mathrm{s}$ to $1000 \mathrm{mV} / \mathrm{s}$. Solution resistance was uncompensated. The electrochemical cell consisted of a Pt-disk (1.6 mm diameter) working electrode, a Pt-wire auxilliary electrode, and a $\mathrm{Ag} / \mathrm{AgNO}_{3}(0.1 \mathrm{M}$ in acetonitrile) reference electrode. All test solutions contained $1 \mathrm{mM}$ of the particular quinoxaline compound and $0.10 \mathrm{M}$ tetrabutylammonium perchlorate (TBAP) as supporting electrolyte. Deoxygenation of test solutions was carried out by passing a gentle and constant stream of prepurified dinitrogen through the solution for 15 minutes. The quinoxaline compound was added to the solution during the deoxygenation and allowed to dissolve. A blanket of dinitrogen was maintained over the solution during all experiments. Half-wave potentials and the difference in peak potentials were calculated using the following equations, [44] respectively: $\mathrm{E}_{1 / 2}=\left(\mathrm{E}_{\mathrm{pa}}+\mathrm{E}_{\mathrm{pc}}\right) / 2$ and $\Delta \mathrm{E}_{\mathrm{p}}=\mathrm{E}_{\mathrm{pa}}-$ $\mathrm{E}_{\mathrm{pc}}$. Ferrocene $(\mathrm{Fc})$ was used as an internal reference redox system to account for daily variations in the reference electrode and liquid junction potentials. [65] $\mathrm{Fc}(1 \mathrm{mM})$ was added to each solution after the voltammetric measurements of the test quinoxaline compound were complete. [66] All potentials are reported versus the ferrocene/ferrocinium $\left(\mathrm{Fc}_{\mathrm{Fc}}{ }^{+}\right)$redox couple, i.e. $\mathrm{E}_{\mathrm{pc}}$, $\mathrm{SRE}-\mathrm{E}_{1 / 2, \mathrm{Fc} / \mathrm{Fc}}+$ or $\mathrm{E}_{1 / 2}, \mathrm{SRE}-\mathrm{E}_{1 / 2, \mathrm{Fc} / \mathrm{Fc}}+$. Half-wave potentials $\left(\mathrm{E}_{1 / 2}\right)$ for ferrocene varied from 
$0.0050 \mathrm{~V}$ to $0.022 \mathrm{~V}$ during the course of this study. Dimethylformamide (DMF) (Fisher Scientific) was used as the solvent. TBAP and ferrocene were obtained from Aldrich Chemical Company. All reagents were obtained in the highest purity available and used without further purification.

Supporting information available: Cyclic voltammetry data obtained for the quinoxaline 1,4di- $N$-oxide derivatives studied derivatives.

*Corresponding author. Telephone: +34 948 425653. Fax: +34 948 425652. E-mail: sperez@unav.es

\section{ACKNOWLEDGMENT}

This work has been carried out with the financial support of FIMA (Fundación para la Investigación Médica Aplicada) from the University of Navarra, CSIC (Comisión de Investigación Científica) from Universidad de la República and Collaborative work was performed under the auspices of the Iberoamerican Program for Science and Technology (CYTED), network RIDIMEDCHAG. J. Varela and E. Birriel are indebted to ANII for fellowships and E. Torres is indebted to the University of Navarra for a grant.

\section{ABBREVIATIONS}

T. cruzi, Trypanosoma cruzi; Nfx, Nifurtimox; Bnz, benznidazole; BFX, Benzofuroxan; PGI, percentage of growth inhibition; $\mathrm{IC}_{50}$, concentration for $50 \%$ growth inhibition; SI, selectivity index; GM, glucose minimal; 4-NPD, 4-nitro-o-phenylendiamine; AF, 2-aminofluorene; NR, number of revertants; TBAP, tetrabutylammonium perchlorate; Fc, ferrocene;

\section{REFERENCES}


[1] Rassi, A., Jr.; Rassi, A.; Marin-Neto, J. A., Chagas disease. Lancet 2010, 375 (9723), 1388402.

[2] Lescure, F. X.; Le Loup, G.; Freilij, H.; Develoux, M.; Paris, L.; Brutus, L.; Pialoux, G., Chagas disease: changes in knowledge and management. The Lancet infectious diseases 2010, $10(8), 556-70$.

[3] Coura, J. R.; Borges-Pereira, J., Chagas disease: 100 years after its discovery. A systemic review. Acta tropica 2010, 115 (1-2), 5-13.

[4] Thirteenth Program Report, UNDP/World Bank/World Health Organization Program for Research and Training in Tropical Diseases; World Health Organization: Geneva, 2010.

[5] www.paho.org/chagas.

[6] Schmunis, G. A., Epidemiology of Chagas disease in non-endemic countries: the role of international migration. Memorias do Instituto Oswaldo Cruz 2007, 102 Suppl 1, 75-85.

[7] Schmunis, G. A.; Yadon, Z. E., Chagas disease: a Latin American health problem becoming a world health problem. Acta tropica 2010, 115 (1-2), 14-21.

[8] Kirchhoff, L. V., Epidemiology of American trypanosomiasis (Chagas disease). Advances in parasitology 2011, 75, 1-18.

[9] Dias, J. C.; Silveira, A. C.; Schofield, C. J., The impact of Chagas disease control in Latin America: a review. Memorias do Instituto Oswaldo Cruz 2002, 97 (5), 603-12.

[10]Urbina, J. A.; Docampo, R., Specific chemotherapy of Chagas disease: controversies and advances. Trends in parasitology 2003, 19 (11), 495-501. 
[11]Urbina, J. A., Specific chemotherapy of Chagas disease: relevance, current limitations and new approaches. Acta tropica 2010, 115 (1-2), 55-68.

[12] Coura, J.R; de Castro, S. L., A critical review on Chagas disease chemotherapy. Memorias do Instituto Oswaldo Cruz 2002, 97 (1), 3-24.

[13]Coura, J. R.; Vinas, P. A., Chagas disease: a new worldwide challenge. Nature 2010, 465 (7301), S6-7.

[14]Carta, A.; Corona, P.; Loriga, M., Quinoxaline 1,4-dioxide: a versatile scaffold endowed with manifold activities. Current medicinal chemistry 2005, 12 (19), 2259-72.

[15]González, M.; Cerecetto, H.; Monge, A. Quinoxaline 1,4-Dioxide and Phenazine 5,10Dioxide. Chemistry and Biology. Topics in Heterocycles Chemistry 2007, 11, 179-211.

[16]Zarranz, B.; Jaso, A.; Aldana, I.; Monge, A., Synthesis and anticancer activity evaluation of new 2-alkylcarbonyl and 2-benzoyl-3-trifluoromethyl-quinoxaline 1,4-di-N-oxide derivatives. Bioorganic \& medicinal chemistry 2004, 12 (13), 3711-21.

[17] Solano, B.; Junnotula, V.; Marin, A.; Villar, R.; Burguete, A.; Vicente, E.; Perez-Silanes, S.; Aldana, I.; Monge, A.; Dutta, S.; Sarkar, U.; Gates, K. S., Synthesis and biological evaluation of new 2-arylcarbonyl-3-trifluoromethylquinoxaline 1,4-di-N-oxide derivatives and their reduced analogues. Journal of medicinal chemistry 2007, 50 (22), 5485-92.

[18] Moreno, E.; Ancizu, S.; Perez-Silanes, S.; Torres, E.; Aldana, I.; Monge, A., Synthesis and antimycobacterial activity of new quinoxaline-2-carboxamide 1,4-di-N-oxide derivatives. European journal of medicinal chemistry 2010, 45 (10), 4418-26. 
[19] Ancizu, S.; Moreno, E.; Torres, E.; Burguete, A.; Perez-Silanes, S.; Benitez, D.; Villar, R.; Solano, B.; Marin, A.; Aldana, I.; Cerecetto, H.; Gonzalez, M.; Monge, A., Heterocyclic-2carboxylic acid (3-cyano-1,4-di-N-oxidequinoxalin-2-yl)amide derivatives as hits for the development of neglected disease drugs. Molecules 2009, 14 (6), 2256-72.

[20]Aguirre, G.; Cerecetto, H.; Di Maio, R.; Gonzalez, M.; Alfaro, M. E.; Jaso, A.; Zarranz, B.; Ortega, M. A.; Aldana, I.; Monge-Vega, A., Quinoxaline N,N'-dioxide derivatives and related compounds as growth inhibitors of Trypanosoma cruzi. Structure-activity relationships. Bioorganic \& medicinal chemistry letters 2004, 14 (14), 3835-9.

[21]Vicente, E.; Duchowicz, P. R.; Benitez, D.; Castro, E. A.; Cerecetto, H.; Gonzalez, M.; Monge, A., Anti-T. cruzi activities and QSAR studies of 3-arylquinoxaline-2-carbonitrile diN-oxides. Bioorganic \& medicinal chemistry letters 2010, 20 (16), 4831-5.

[22] Torres, E.; Moreno, E.; Ancizu, S.; Barea, C.; Galiano, S.; Aldana, I.; Monge, A.; PerezSilanes, S., New 1,4-di-N-oxide-quinoxaline-2-ylmethylene isonicotinic acid hydrazide derivatives as anti-Mycobacterium tuberculosis agents. Bioorganic \& medicinal chemistry letters 2011, 21 (12), 3699-703.

[23] Burguete, A.; Pontiki, E.; Hadjipavlou-Litina, D.; Ancizu, S.; Villar, R.; Solano, B.; Moreno, E.; Torres, E.; Perez, S.; Aldana, I.; Monge, A., Synthesis and biological evaluation of new quinoxaline derivatives as antioxidant and anti-inflammatory agents. Chemical biology \& drug design 2011, 77 (4), 255-67.

[24]Barea, C.; Pabon, A.; Castillo, D.; Zimic, M.; Quiliano, M.; Galiano, S.; Perez-Silanes, S.; Monge, A.; Deharo, E.; Aldana, I., New salicylamide and sulfonamide derivatives of 
quinoxaline 1,4-di-N-oxide with antileishmanial and antimalarial activities. Bioorganic \& medicinal chemistry letters 2011, 21 (15), 4498-502.

[25]Barea, C.; Pabon, A.; Galiano, S.; Perez-Silanes, S.; Gonzalez, G.; Deyssard, C.; Monge, A.; Deharo, E.; Aldana, I., Antiplasmodial and leishmanicidal activities of 2-cyano-3-(4phenylpiperazine-1-carboxamido) quinoxaline 1,4-dioxide derivatives. Molecules 2012, 17 (8), 9451-61.

[26] Vicente, E.; Charnaud, S.; Bongard, E.; Villar, R.; Burguete, A.; Solano, B.; Ancizu, S.; Perez-Silanes, S.; Aldana, I.; Vivas, L.; Monge, A., Synthesis and antiplasmodial activity of 3-furyl and 3-thienylquinoxaline-2-carbonitrile 1,4-di-N-oxide derivatives. Molecules 2008, $13(1), 69-77$.

[27]Benitez, D.; Cabrera, M.; Hernandez, P.; Boiani, L.; Lavaggi, M. L.; Di Maio, R.; Yaluff, G.; Serna, E.; Torres, S.; Ferreira, M. E.; Vera de Bilbao, N.; Torres, E.; Perez-Silanes, S.; Solano, B.; Moreno, E.; Aldana, I.; Lopez de Cerain, A.; Cerecetto, H.; Gonzalez, M.; Monge, A., 3-Trifluoromethylquinoxaline N,N'-dioxides as anti-trypanosomatid agents. Identification of optimal anti-T. cruzi agents and mechanism of action studies. Journal of medicinal chemistry 2011, 54 (10), 3624-36.

[28] Mavandadi, F.; Pilotti, A., The impact of microwave-assisted organic synthesis in drug discovery. Drug discovery today 2006, 11 (3-4), 165-74.

[29]Larhed, M.; Hallberg, A., Microwave-assisted high-speed chemistry: a new technique in drug discovery. Drug discovery today 2001, 6 (8), 406-416. 
[30] Kappe, C. O.; Dallinger, D., The impact of microwave synthesis on drug discovery. Nature reviews. Drug discovery 2006, 5 (1), 51-63.

[31] Wathey, B.; Tierney, J.; Lidstrom, P.; Westman, J., The impact of microwave-assisted organic chemistry on drug discovery. Drug discovery today 2002, 7 (6), 373-80.

[32] Ancizu, S.; Moreno, E.; Solano, B.; Villar, R.; Burguete, A.; Torres, E.; Perez-Silanes, S.; Aldana, I.; Monge, A., New 3-methylquinoxaline-2-carboxamide 1,4-di-N-oxide derivatives as anti-Mycobacterium tuberculosis agents. Bioorganic \& medicinal chemistry 2010, 18 (7), 2713-9.

[33]Boiani, L.; Aguirre, G.; Gonzalez, M.; Cerecetto, H.; Chidichimo, A.; Cazzulo, J. J.; Bertinaria, M.; Guglielmo, S., Furoxan-, alkylnitrate-derivatives and related compounds as anti-trypanosomatid agents: mechanism of action studies. Bioorganic \& medicinal chemistry 2008, $16(17), 7900-7$.

[34]Boiani, M.; Piacenza, L.; Hernandez, P.; Boiani, L.; Cerecetto, H.; Gonzalez, M.; Denicola, A., Mode of action of nifurtimox and N-oxide-containing heterocycles against Trypanosoma cruzi: is oxidative stress involved? Biochemical pharmacology 2010, 79 (12), 1736-45.

[35]Ames, B. N.; McCann, J.; Yamasaki, E., Methods for detecting carcinogens and mutagens with the Salmonella/mammalian-microsome mutagenicity test. Mutation research 1975,31 (6), 347-64.

[36] Ortega, M. A.; Sainz, Y.; Montoya, M. E.; Jaso, A.; Zarranz, B.; Aldana, I.; Monge, A., Anti-Mycobacterium tuberculosis agents derived from quinoxaline-2-carbonitrile and quinoxaline-2-carbonitrile 1,4-di-N-oxide. Arzneimittel-Forschung 2002, 52 (2), 113-9. 
[37] Faucher, J. F.; Baltz, T.; Petry, K. G., Detection of an "epimastigote-like” intracelular stage of Tripanosma Cruzi. Parasitology Research 1995, 81, 441-43.

[38] Almeida-de Faría, M.; Freymuller, E.; Colli, W.; Alves, M. J., Trypanosoma cruzi: characterization of an intracellular epimastigote-like form. Experimental Parasitology 1999, $92,263-74$

[39] Tyler, K. M.; Engman, D. M., The life cycle of Trypanosoma cruzi revisited. International Journal of Parasitology 2001, 31, 472-81.

[40]Bonnet-Delpon, D., [Fluorine, an essential element for medicinal chemistry]. Annales pharmaceutiques francaises 2008, 66 (1), 56-9.

[41]Purser, S.; Moore, P. R.; Swallow, S.; Gouverneur, V., Fluorine in medicinal chemistry. Chemical Society reviews 2008, 37 (2), 320-30.

[42] Shah, P.; Westwell, A. D., The role of fluorine in medicinal chemistry. Journal of enzyme inhibition and medicinal chemistry 2007, 22 (5), 527-40.

[43] Porcal, W.; Hernandez, P.; Aguirre, G.; Boiani, L.; Boiani, M.; Merlino, A.; Ferreira, A.; Di Maio, R.; Castro, A.; Gonzalez, M.; Cerecetto, H., Second generation of 5ethenylbenzofuroxan derivatives as inhibitors of Trypanosoma cruzi growth: synthesis, biological evaluation, and structure-activity relationships. Bioorganic \& medicinal chemistry 2007, 15 (7), 2768-81.

[44] Rieger, P. H., Electrochemistry. Ed. Chapman and Hall: New York, 1994. 
[45]Bard A.J., Faulkner. L. R., Electrochemical Methods: Fundamentals and Applications 2nd ed. Wiley: New York, 2001.

[46]Ryan, M. D.; Scamehorn, R. G.; Kovacic, P., Charge transfer in the mechanism of drug action involving quinoxaline di-N-oxides. Journal of pharmaceutical sciences 1985, 74 (4), $492-5$

[47]Crawford, P. W.; Scamehorn, R. G.; Hollstein, U.; Ryan, M. D.; Kovacic, P., Cyclic voltammetry of phenazines and quinoxalines including mono- and di-N-oxides. Relation to structure and antimicrobial activity. Chemico-biological interactions 1986, 60 (1), 67-84.

[48] Ames, J. R.; Houghtaling, M. A.; Terrian, D. L., Cyclic voltammetry of some quinoxaline di-N-oxides and quinoxalines in dimethylformamide. Electrochimica Acta 1992, 37 (8), $1433-1436$.

[49] Miyazaki, H.; Matsuhisa, Y.; T. Kubota., Cyclic voltammetry of aromatic amine N-oxides in nonaqueous solvents and the stability of the free radicals produced. Bulletin of the Chemical Society of Japan 1981, 54, 3850.

[50]Moreno, E.; Pérez-Silanes, S.; Gouravaram, S.; Macharam, A.; Ancizu, S.; Torres, E.; Aldana, I.; Monge, A.; Crawford, P. W., 1,4-Di-N-oxide quinoxaline-2-carboxamide: Cyclic voltammetry and relationship between electrochemical behavior, structure and antituberculosis activity. Electrochimica Acta 2011, 56 (9), 3270-3275.

[51]Pérez-Silanes, S.; Devarapally, G.; Torres, E.; Moreno, E.; Aldana, I.; Monge, A.; Crawford, P. W., Cyclic Voltammetric Study of Some Anti-Chagas Active Quinoxaline 1,4-Di-NOxide-2-Ketone Derivatives. Helvetica Chimica Acta, 2013, 96, 217-227 
[52]Barqawi, K. R.; Atfah, M. A., A cyclic voltammetric study of some quinoxaline di-n-oxides and quinoxalines in acetonitrile: substituent effect on the cathodic reduction. Electrochimica Acta 1987, 32 (4), 597-599.

[53]Zuman, P., Substituent Effects in Organic Polarography. New York: 1967.

[54]Aguirre, G.; Cerecetto, H.; Di Maio, R.; Gonzalez, M.; Porcal, W.; Seoane, G.; Ortega, M. A.; Aldana, I.; Monge, A.; Denicola, A., Benzo[1,2-c]1,2,5-oxadiazole N-oxide derivatives as potential antitrypanosomal drugs. Structure-activity relationships. Part II. Archiv der Pharmazie 2002, 335 (1), 15-21.

[55] Aguirre, G.; Boiani, M.; Cerecetto, H.; Gerpe, A.; Gonzalez, M.; Sainz, Y. F.; Denicola, A.; De Ocariz, C. O.; Nogal, J. J.; Montero, D.; Escario, J. A., Novel antiprotozoal products: imidazole and benzimidazole N-oxide derivatives and related compounds. Archiv der Pharmazie 2004, 337 (5), 259-70.

[56] Aguirre, G.; Boiani, L.; Boiani, M.; Cerecetto, H.; Di Maio, R.; Gonzalez, M.; Porcal, W.; Denicola, A.; Piro, O. E.; Castellano, E. E.; Sant'Anna, C. M.; Barreiro, E. J., New potent 5substituted benzofuroxans as inhibitors of Trypanosoma cruzi growth: quantitative structureactivity relationship studies. Bioorganic \& medicinal chemistry 2005, 13 (23), 6336-46.

[57]Caterina, M. C.; Perillo, I. A.; Boiani, L.; Pezaroglo, H.; Cerecetto, H.; Gonzalez, M.; Salerno, A., Imidazolidines as new anti-Trypanosoma cruzi agents: biological evaluation and structure-activity relationships. Bioorganic \& medicinal chemistry 2008, 16 (5), 222634. 
[58] Aran, V. J.; Ochoa, C.; Boiani, L.; Buccino, P.; Cerecetto, H.; Gerpe, A.; Gonzalez, M.; Montero, D.; Nogal, J. J.; Gomez-Barrio, A.; Azqueta, A.; Lopez de Cerain, A.; Piro, O. E.; Castellano, E. E., Synthesis and biological properties of new 5-nitroindazole derivatives. Bioorganic \& medicinal chemistry 2005, 13 (9), 3197-207.

[59]Gerpe, A.; Alvarez, G.; Benitez, D.; Boiani, L.; Quiroga, M.; Hernandez, P.; Sortino, M.; Zacchino, S.; Gonzalez, M.; Cerecetto, H., 5-Nitrofuranes and 5-nitrothiophenes with antiTrypanosoma cruzi activity and ability to accumulate squalene. Bioorganic \& medicinal chemistry 2009, 17 (21), 7500-9.

[60]Maron, D. M.; Ames, B. N., Revised methods for the Salmonella mutagenicity test. Mutation research 1983, 113 (3-4), 173-215.

[61]Mortelmans, K.; Zeiger, E., The Ames Salmonella/microsome mutagenicity assay. Mutation research 2000, 455 (1-2), 29-60.

[62] Cabrera, M.; Lavaggi, M. L.; Hernandez, P.; Merlino, A.; Gerpe, A.; Porcal, W.; Boiani, M.; Ferreira, A.; Monge, A.; de Cerain, A. L.; Gonzalez, M.; Cerecetto, H., Cytotoxic, mutagenic and genotoxic effects of new anti-T. cruzi 5-phenylethenylbenzofuroxans. Contribution of phase I metabolites on the mutagenicity induction. Toxicology letters 2009, 190 (2), 140-9.

[63] Guengerich, F. P., Cytochrome P450s and other enzymes in drug metabolism and toxicity. The AAPS journal 2006, 8 (1), E101-11. 
[64]Chu, K. C.; Patel, K. M.; Lin, A. H.; Tarone, R. E.; Linhart, M. S.; Dunkel, V. C., Evaluating statistical analyses and reproducibility of microbial mutagenicity assays. Mutation research 1981, 85 (3), 119-32.

[65] Gritzner, G.; Kuta, J., Recommendations on reporting electrode potentials in noaqueous solvents. Pure Applied Chemistry 1984, 56 (4), 461-66.

[66] Strier, M. P.; Cavagnol, J. C., The Polarography of Quinoxaline II. 6-Substituted Derivatives. Journal of American Chemical Society 1958, 80, 1565-68.

\section{Figure legends}

Figure 1. One electron reduction of quinoxaline 1,4-di- $N$-oxides to form a radical anion.

Scheme 1. Structure-activity relationships observed and used for the design of novel derivatives.

Scheme 2. Synthetic procedures used to prepare compounds 1-18: (I) $\mathrm{K}_{2} \mathrm{CO}_{3}$, acetone, room temperature. (II) $\mathrm{Et}_{3} \mathrm{~N}$, toluene, microwave assisted method $\left(60 \mathrm{~W}, 40-60 \mathrm{~min}, 70^{\circ} \mathrm{C}\right)$.

Chart 1. Comparison of reaction yields, after purification, obtained by synthetic methods I and II.

Chart 2. Plot of reduction potentials $\left(\mathrm{E}_{1 / 2} \mathrm{vs} . \mathrm{Fc} / \mathrm{Fc}^{+}\right)$for the first voltammetric wave of quinoxaline 1,4-di- $N$-oxide-2-alkyl carboxylates against the percentage of growth inhibition (PGI\%). 
Table 1. Comparison of reaction times obtained by synthetic methods I and II.

Table 2. Structure, anti-T. cruzi activity and cyclic voltammetry data of quinoxaline derivatives.

Table 3. Biological characterization of new Quinoxaline 1,4-di- $N$-oxide against Mammal Macrophages

Table 4. Revertants in Salmonella typhimurium TA98 strain treated with different doses of compounds $\mathbf{1}-\mathbf{1 8}$ for the two different treatment procedures (-S9 and $+\mathrm{S} 9)$.

\section{Figure 1}

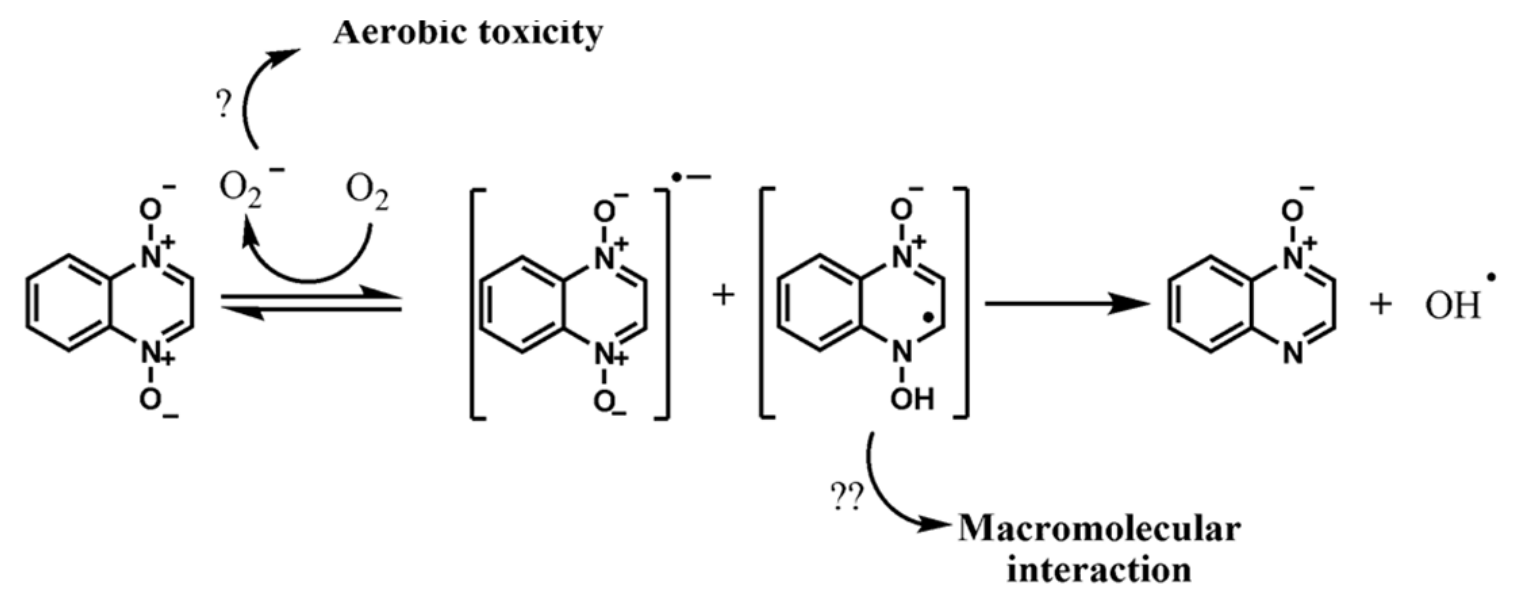


Scheme 1

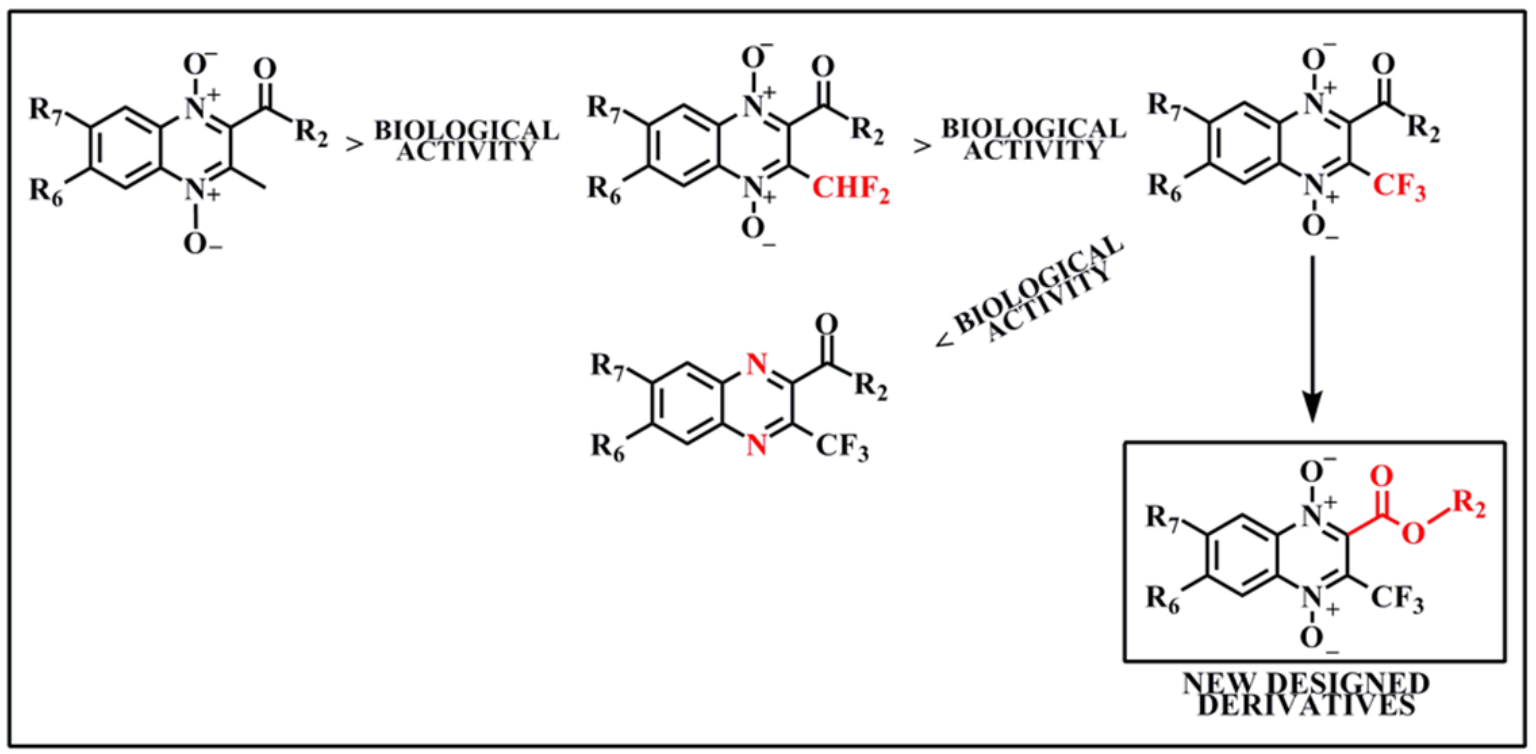

Scheme 2

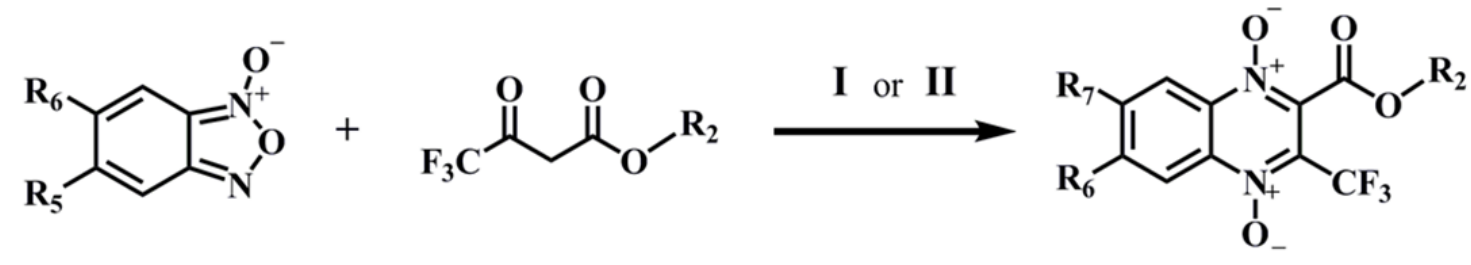

(1-18) 


\section{Chart 1}

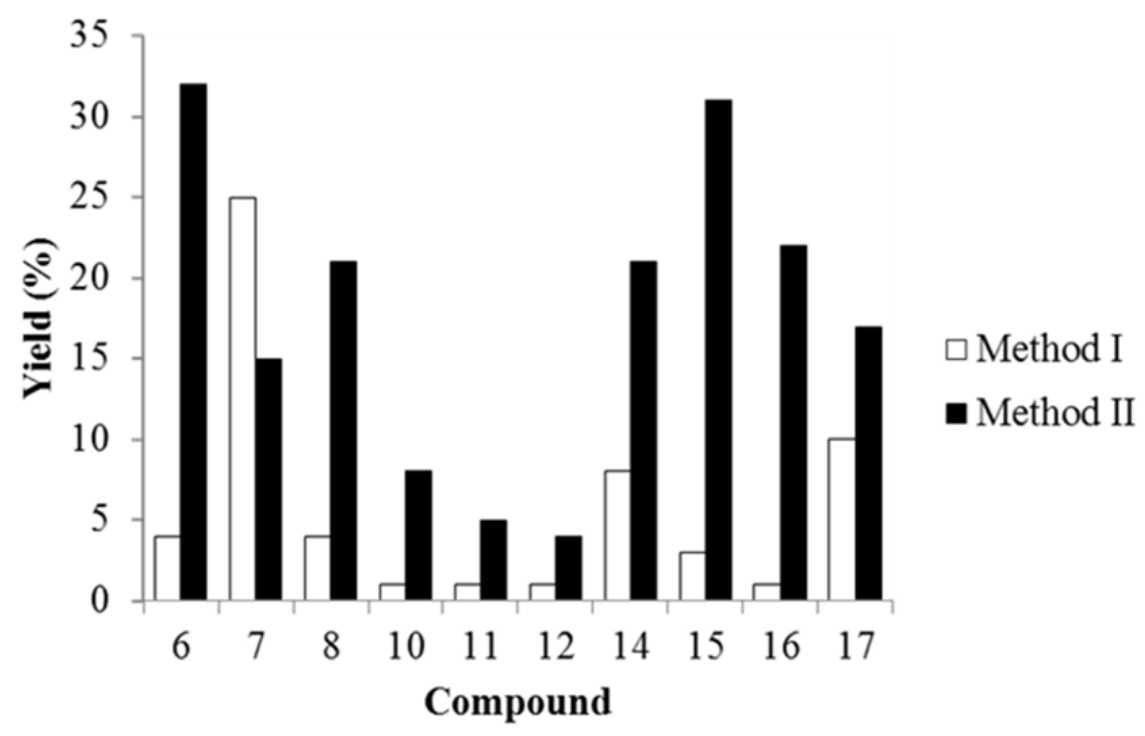

Chart 2

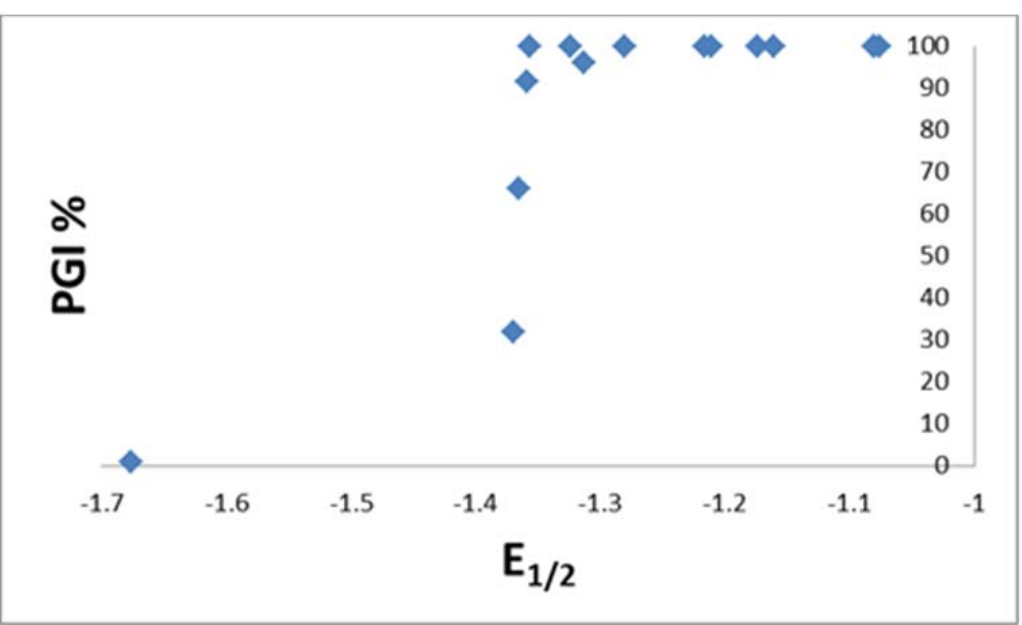


Table 1

REACTION TIMES

\begin{tabular}{l|ll}
\hline COMP. & METHOD I & METHOD II \\
\hline $\mathbf{6}$ & 1 day & $50 \mathrm{~min}$ \\
\hline $\mathbf{7}$ & 2 day & $50 \mathrm{~min}$ \\
\hline $\mathbf{8}$ & 1 day & $60 \mathrm{~min}$ \\
\hline $\mathbf{1 0}$ & 3 day & $50 \mathrm{~min}$ \\
\hline $\mathbf{1 1}$ & 4 day & $70 \mathrm{~min}$ \\
\hline $\mathbf{1 2}$ & 7 day & $52 \mathrm{~min}$ \\
\hline $\mathbf{1 4}$ & 1 day & $65 \mathrm{~min}$ \\
\hline $\mathbf{1 5}$ & 1 day & $65 \mathrm{~min}$ \\
\hline $\mathbf{1 6}$ & 15 h & $50 \mathrm{~min}$ \\
\hline $\mathbf{1 7}$ & 1 day & $50 \mathrm{~min}$ \\
\hline
\end{tabular}


Table 2

\begin{tabular}{|c|c|c|c|c|c|c|c|}
\hline \multirow[b]{2}{*}{ Code } & \multirow[b]{2}{*}{$-\mathrm{R}_{2}$} & \multirow[b]{2}{*}{$-\mathrm{R}_{3}$} & \multirow[b]{2}{*}{$-\mathrm{R}_{6}$} & \multirow[b]{2}{*}{$-\mathrm{R}_{7}$} & \multicolumn{2}{|c|}{$\begin{array}{l}\text { Anti-T. cruzi } \\
\text { activity }\end{array}$} & \multirow{2}{*}{$\begin{array}{l}\text { Cyclic } \\
\text { voltammetry } \\
\mathrm{E}_{1 / 2}(\mathrm{~V})\end{array}$} \\
\hline & & & & & $\begin{array}{l}\mathrm{PGI}^{\mathrm{a}} \\
(\%)\end{array}$ & $\begin{array}{l}\mathrm{IC}_{50} \\
(\mu \mathrm{M})^{\mathrm{b}}\end{array}$ & \\
\hline$A^{d}$ & $-\mathrm{CH}_{2} \mathrm{CH}_{3}$ & $-\mathrm{CH}_{3}$ & $-\mathrm{CH}_{3}$ & $-\mathrm{CH}_{3}$ & 1 & - & -1.677 \\
\hline $\mathbf{B}^{\mathbf{d}}$ & $-\mathrm{CH}_{2} \mathrm{CH}_{3}$ & $-\mathrm{CH}_{3}$ & $-\mathrm{Cl}$ & $-\mathrm{Cl}$ & 32 & - & -1.370 \\
\hline$C^{d}$ & $-\mathrm{CH}_{3}$ & $-\mathrm{CH}_{3}$ & $-\mathrm{Cl}$ & $-\mathrm{Cl}$ & 66 & - & -1.366 \\
\hline 1 & $-\mathrm{CH}_{3}$ & $-\mathrm{CF}_{3}$ & $-\mathrm{H}$ & $-\mathrm{H}$ & 100.0 & 2.6 & -1.313 \\
\hline 2 & $-\mathrm{CH}_{3}$ & $-\mathrm{CF}_{3}$ & $-\mathrm{H}$ & $-\mathrm{CH}_{3} \mathrm{O}$ & 86.6 & 4.6 & N. D. ${ }^{c}$ \\
\hline 3 & $-\mathrm{CH}_{3}$ & $-\mathrm{CF}_{3}$ & $-\mathrm{H}$ & $-\mathrm{CH}_{3}$ & 96.1 & 13.7 & N. D. ${ }^{\mathrm{c}}$ \\
\hline 4 & $-\mathrm{CH}_{3}$ & $-\mathrm{CF}_{3}$ & $-\mathrm{CH}_{3}$ & $-\mathrm{CH}_{3}$ & 91.6 & 5.0 & -1.359 \\
\hline 5 & $-\mathrm{CH}_{3}$ & $-\mathrm{CF}_{3}$ & $-\mathrm{H}$ & $-\mathrm{Cl}$ & 100.0 & 1.8 & N. D. ${ }^{c}$ \\
\hline 6 & $-\mathrm{CH}_{3}$ & $-\mathrm{CF}_{3}$ & $-\mathrm{Cl}$ & $-\mathrm{Cl}$ & 100.0 & 10.8 & -1.076 \\
\hline 7 & $-\mathrm{CH}_{3}$ & $-\mathrm{CF}_{3}$ & $-\mathrm{H}$ & $-F$ & 100.0 & 3.5 & -1.211 \\
\hline 8 & $-\mathrm{CH}_{3}$ & $-\mathrm{CF}_{3}$ & $-F$ & $-F$ & 100.0 & 1.5 & -1.160 \\
\hline 9 & $-\mathrm{CH}_{3}$ & $-\mathrm{CF}_{3}$ & $-\mathrm{H}$ & $-\mathrm{CF}_{3}$ & 100.0 & 5.0 & -1.081 \\
\hline 10 & $-\mathrm{CH}_{2} \mathrm{CH}_{3}$ & $-\mathrm{CF}_{3}$ & $-\mathrm{H}$ & $-\mathrm{H}$ & 100.0 & 4.0 & -1.281 \\
\hline 11 & $-\mathrm{CH}_{2} \mathrm{CH}_{3}$ & $-\mathrm{CF}_{3}$ & $-\mathrm{H}$ & $-\mathrm{CH}_{3} \mathrm{O}$ & 100.0 & 4.8 & -1.357 \\
\hline 12 & $-\mathrm{CH}_{2} \mathrm{CH}_{3}$ & $-\mathrm{CF}_{3}$ & $-\mathrm{H}$ & $-\mathrm{CH}_{3}$ & 100.0 & 4.8 & -1.324 \\
\hline 13 & $-\mathrm{CH}_{2} \mathrm{CH}_{3}$ & $-\mathrm{CF}_{3}$ & $-\mathrm{CH}_{3}$ & $-\mathrm{CH}_{3}$ & 87.5 & 7.6 & N. D. ${ }^{\mathrm{c}}$ \\
\hline 14 & $-\mathrm{CH}_{2} \mathrm{CH}_{3}$ & $-\mathrm{CF}_{3}$ & $-\mathrm{H}$ & $-\mathrm{Cl}$ & 100.0 & 1.8 & -1.174 \\
\hline 15 & $-\mathrm{CH}_{2} \mathrm{CH}_{3}$ & $-\mathrm{CF}_{3}$ & $-\mathrm{Cl}$ & $-\mathrm{Cl}$ & 100.0 & 2.9 & -1.081 \\
\hline
\end{tabular}




\begin{tabular}{llllllll}
16 & $-\mathrm{CH}_{2} \mathrm{CH}_{3}$ & $-\mathrm{CF}_{3}$ & $-\mathrm{H}$ & $-\mathrm{F}$ & 100.0 & 3.3 & -1.216 \\
$\mathbf{1 7}$ & $-\mathrm{CH}_{2} \mathrm{CH}_{3}$ & $-\mathrm{CF}_{3}$ & $-\mathrm{F}$ & $-\mathrm{F}$ & 100.0 & 0.4 & -1.161 \\
$\mathbf{1 8}$ & $-\mathrm{CH}_{2} \mathrm{CH}_{3}$ & $-\mathrm{CF}_{3}$ & $-\mathrm{H}$ & $-\mathrm{CF}_{3}$ & 100.0 & 1.0 & N .D. ${ }^{\mathrm{c}}$ \\
\hline \multicolumn{2}{l}{ Nifurtimox } & & & & & & \\
\hline
\end{tabular}

${ }^{\text {a }}$ Percentage of growth inhibition. Inhibition of epimastigote growth of Tulahuen 2 strain, dose $=$ $25 \mu \mathrm{M}$. The results are the mean of three independent experiments with a SD less than $10 \%$ in all cases.

${ }^{\mathrm{b}} \mathrm{IC}_{50}$ : concentration (in $\mu \mathrm{M}$ ) that inhibits $50 \%$ of epimastigote form of $T$. cruzi growth. The results are the mean of three independent experiments with a SD less than $10 \%$ in all cases.

${ }^{\mathrm{c}}$ Not determined.

${ }^{\mathrm{d} C}$ Compounds previously published (Journal of medicinal chemistry 2011, 54 (10), 3624-36). 
Table 3

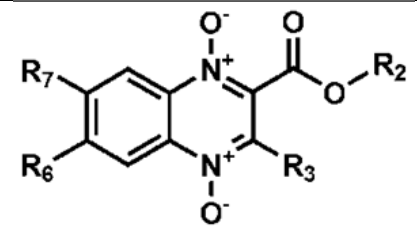

Cytotoxicity

\begin{tabular}{|c|c|c|c|c|c|c|}
\hline Code & $-\mathrm{R}_{2}$ & $-R_{3}$ & $-\mathrm{R}_{6}$ & $-\mathrm{R}_{7}$ & $\begin{array}{l}\mathrm{IC}_{50} \\
(\mu \mathrm{M})^{\mathrm{a}}\end{array}$ & $\mathrm{SI}^{\mathrm{b}}$ \\
\hline 1 & $-\mathrm{CH}_{3}$ & $-\mathrm{CF}_{3}$ & $-\mathrm{H}$ & $-\mathrm{H}$ & 19.0 & 7.3 \\
\hline 3 & $-\mathrm{CH}_{3}$ & $-\mathrm{CF}_{3}$ & $-\mathrm{H}$ & $-\mathrm{CH}_{3}$ & 4.0 & 0.3 \\
\hline 4 & $-\mathrm{CH}_{3}$ & $-\mathrm{CF}_{3}$ & $-\mathrm{CH}_{3}$ & $-\mathrm{CH}_{3}$ & 4.0 & 0.8 \\
\hline 6 & $-\mathrm{CH}_{3}$ & $-\mathrm{CF}_{3}$ & $-\mathrm{Cl}$ & $-\mathrm{Cl}$ & 0.5 & $<0.1$ \\
\hline 7 & $-\mathrm{CH}_{3}$ & $-\mathrm{CF}_{3}$ & $-\mathrm{H}$ & $-F$ & 2.5 & 0.7 \\
\hline 9 & $-\mathrm{CH}_{3}$ & $-\mathrm{CF}_{3}$ & $-\mathrm{H}$ & $-\mathrm{CF}_{3}$ & 4.0 & 0.8 \\
\hline 10 & $-\mathrm{CH}_{2} \mathrm{CH}_{3}$ & $-\mathrm{CF}_{3}$ & $-\mathrm{H}$ & $-\mathrm{H}$ & 4.0 & 1.0 \\
\hline 11 & $-\mathrm{CH}_{2} \mathrm{CH}_{3}$ & $-\mathrm{CF}_{3}$ & $-\mathrm{H}$ & $-\mathrm{CH}_{3} \mathrm{O}$ & 6.0 & 1.2 \\
\hline 12 & $-\mathrm{CH}_{2} \mathrm{CH}_{3}$ & $-\mathrm{CF}_{3}$ & $-\mathrm{H}$ & $-\mathrm{CH}_{3}$ & 7.0 & 1.4 \\
\hline 13 & $-\mathrm{CH}_{2} \mathrm{CH}_{3}$ & $-\mathrm{CF}_{3}$ & $-\mathrm{CH}_{3}$ & $-\mathrm{CH}_{3}$ & 4.0 & 0.5 \\
\hline 16 & $-\mathrm{CH}_{2} \mathrm{CH}_{3}$ & $-\mathrm{CF}_{3}$ & $-\mathrm{H}$ & $-F$ & 0.5 & 0.1 \\
\hline 17 & $-\mathrm{CH}_{2} \mathrm{CH}_{3}$ & $-\mathrm{CF}_{3}$ & $-F$ & $-F$ & 4.0 & 10 \\
\hline 18 & $-\mathrm{CH}_{2} \mathrm{CH}_{3}$ & $-\mathrm{CF}_{3}$ & $-\mathrm{H}$ & $-\mathrm{CF}_{3}$ & 4.2 & 4.2 \\
\hline \multicolumn{2}{|c|}{ Nifurtimox $^{c}$} & & & & 316.0 & 41.0 \\
\hline
\end{tabular}

${ }^{\mathrm{a}} \mathrm{IC}_{50}$ : concentration (in $\mu \mathrm{M}$ ) that inhibits $50 \%$ of $\mathrm{J}-774$ murine macrophage-like cells growth after $48 \mathrm{~h}$ of incubation. The results are the mean of three independent experiments with a SD less than $10 \%$ in all cases.

${ }^{\mathrm{b}}$ Selectivity index :expressed as the ratio of $\mathrm{IC}_{50}$ in macrophages to $\mathrm{IC}_{50}$ in $T$. cruzi Tulahuen 2 strain.

${ }^{\mathrm{c}}$ Data from Bioorganic \& medicinal chemistry 2007, 15 (7), 2768-81. 
Table 4

\begin{tabular}{|c|c|c|c|c|c|c|c|c|c|c|c|}
\hline \multirow{2}{*}{ Comp } & \multicolumn{3}{|c|}{ N. R. ${ }^{b}$} & \multicolumn{4}{|c|}{ N. R. ${ }^{b}$} & & & & \multirow{2}{*}{ +S9 } \\
\hline & $\mathrm{D}^{\mathrm{a}}$ & -S9 & $+\mathrm{S} 9$ & Comp & $\mathrm{D}^{\mathrm{a}}$ & -S9 & $+\mathrm{S} 9$ & Comp & $\mathrm{D}^{\mathrm{a}}$ & -S9 & \\
\hline 1 & 0.0 & $27 \pm 7$ & $28 \pm 7$ & 7 & 0.0 & $27 \pm 7$ & $28 \pm 7$ & 13 & 0.0 & $29 \pm 1$ & $30 \pm 7$ \\
\hline \multirow{5}{*}{$(+)$} & 0.06 & $17 \pm 4$ & $17 \pm 3$ & & 0.3 & $15 \pm 7$ & $22 \pm 7$ & \multirow{5}{*}{$(+)^{*}$} & 0.06 & $25 \pm 4$ & $32 \pm 3$ \\
\hline & 0.18 & $25 \pm 5$ & $25 \pm 5$ & & 0.92 & $20 \pm 4$ & $22 \pm 9$ & & 0.18 & $40 \pm 14$ & $37 \pm 9$ \\
\hline & 0.5 & $33 \pm 8$ & $30 \pm 9$ & $(+)^{*}$ & 2.7 & $39 \pm 15$ & $27 \pm 7$ & & 0.5 & $57 \pm 2$ & $45 \pm 5$ \\
\hline & 1.6 & $118 \pm 11$ & $45 \pm 2$ & & 8.3 & $115 \pm 5$ & $27 \pm 4$ & & 1.6 & $174 \pm 12$ & $38 \pm 1$ \\
\hline & 5 & $227 \pm 79$ & $84 \pm 15$ & & 25 & $158 \pm 28$ & $41 \pm 11$ & & 12.5 & $352 \pm 11$ & $71 \pm 10$ \\
\hline \multirow{6}{*}{$\begin{array}{l}2 \\
(+)\end{array}$} & 0.0 & $29 \pm 1$ & $28 \pm 4$ & 8 & 0.0 & $29 \pm 1$ & $28 \pm 4$ & \multirow{4}{*}{$\begin{array}{l}14 \\
(+)^{*}\end{array}$} & 0.0 & $13 \pm 2$ & $30 \pm 7$ \\
\hline & 0.3 & $29 \pm 4$ & $31 \pm 4$ & \multirow{5}{*}{$(+)^{*}$} & 0.06 & $30 \pm 9$ & $31 \pm 3$ & & 0.06 & $14 \pm 4$ & $32 \pm 3$ \\
\hline & 0.92 & $47 \pm 8$ & $41 \pm 2$ & & 0.18 & $33 \pm 2$ & $34 \pm 9$ & & 0.18 & $11 \pm 3$ & $37 \pm 9$ \\
\hline & 2.7 & $70 \pm 6$ & $66 \pm 6$ & & 0.5 & $45 \pm 1$ & $30 \pm 5$ & & 0.5 & $20 \pm 1$ & $45 \pm 5$ \\
\hline & 8.3 & $285 \pm 10$ & $245 \pm 15$ & & 1.6 & $118 \pm 17$ & $29 \pm 7$ & & 1.6 & $31 \pm 4$ & $38 \pm 1$ \\
\hline & 25 & $379 \pm 31$ & $680 \pm 17$ & & 5 & $247 \pm 34$ & $33 \pm 3$ & & 5 & $55 \pm 11$ & $71 \pm 10$ \\
\hline \multirow{6}{*}{$\begin{array}{l}3 \\
(+)\end{array}$} & 0.0 & $13 \pm 2$ & $19 \pm 3$ & 9 & 0.0 & $27 \pm 7$ & $28 \pm 8$ & \multirow{6}{*}{$\begin{array}{l}15 \\
(-)\end{array}$} & 0.0 & $29 \pm 1$ & $29 \pm 1$ \\
\hline & 0.06 & $15 \pm 1$ & $15 \pm 4$ & & 0.06 & $25 \pm 4$ & $25 \pm 2$ & & 0.06 & $29 \pm 1$ & $30 \pm 7$ \\
\hline & 0.18 & $21 \pm 2$ & $13 \pm 1$ & & 0.18 & $23 \pm 3$ & $26 \pm 11$ & & 0.18 & $27 \pm 5$ & $31 \pm 13$ \\
\hline & 0.5 & $26 \pm 11$ & $16 \pm 1$ & $(-)$ & 0.5 & $24 \pm 2$ & $25 \pm 9$ & & 0.5 & $29 \pm 1$ & $27 \pm 3$ \\
\hline & 1.6 & $79 \pm 9$ & $29 \pm 5$ & & 1.6 & $24 \pm 5$ & $20 \pm 6$ & & 1.6 & $32 \pm 4$ & $25 \pm 4$ \\
\hline & 5 & $136 \pm 24$ & $100 \pm 8$ & & 5 & $25 \pm 1$ & $41 \pm 15$ & & 5 & $37 \pm 1$ & $34 \pm 7$ \\
\hline \multirow[t]{6}{*}{4} & 0.0 & $13 \pm 2$ & $19 \pm 3$ & 10 & 0.0 & $29 \pm 1$ & $28 \pm 4$ & \multirow{4}{*}{$\begin{array}{l}16 \\
(+)^{*}\end{array}$} & 0.0 & $27 \pm 7$ & $28 \pm 8$ \\
\hline & 0.61 & $10 \pm 1$ & $18 \pm 2$ & \multirow{5}{*}{$(+)^{*}$} & 0.06 & $32 \pm 1$ & $31 \pm 7$ & & 0.06 & $16 \pm 1$ & $24 \pm 1$ \\
\hline & 1.85 & $18 \pm 12$ & $19 \pm 4$ & & 0.18 & $31 \pm 12$ & $36 \pm 4$ & & 0.18 & $24 \pm 7$ & $23 \pm 5$ \\
\hline & 5.5 & $22 \pm 6$ & $16 \pm 1$ & & 0.5 & $45 \pm 4$ & $29 \pm 5$ & & 0.5 & $42 \pm 2$ & $28 \pm 5$ \\
\hline & 16.6 & $53 \pm 8$ & $74 \pm 11$ & & 1.6 & $109 \pm 8$ & $27 \pm 2$ & & 1.6 & $80 \pm 9$ & $30 \pm 5$ \\
\hline & 50 & $73 \pm 12$ & $260 \pm 23$ & & 5 & $237 \pm 6$ & $44 \pm 5$ & & 5 & $152 \pm 43$ & $25 \pm 5$ \\
\hline
\end{tabular}




\begin{tabular}{|c|c|c|c|c|c|c|c|c|c|c|c|}
\hline 5 & 0.0 & $27 \pm 7$ & $28 \pm 8$ & 11 & 0.0 & $27 \pm 7$ & $28 \pm 8$ & 17 & 0.0 & $13 \pm 2$ & $19 \pm 3$ \\
\hline & $1.2 \times 10^{-3}$ & $19 \pm 1$ & $22 \pm 2$ & & 0.3 & $15 \pm 1$ & $24 \pm 3$ & & 0.06 & $13 \pm 3$ & $17 \pm 2$ \\
\hline & $3.7 \times 10^{-3}$ & $21 \pm 5$ & $20 \pm 1$ & & 0.92 & $25 \pm 2$ & $25 \pm 10$ & & 0.18 & $10 \pm 5$ & $17 \pm 2$ \\
\hline$(+)^{*}$ & 0.011 & $20 \pm 1$ & $24 \pm 3$ & $(+)$ & 2.7 & $40 \pm 9$ & $30 \pm 5$ & $(+)^{*}$ & 0.5 & $16 \pm 7$ & $21 \pm 1$ \\
\hline & 0.033 & $40 \pm 8$ & $24 \pm 4$ & & 8.3 & $133 \pm 20$ & $36 \pm 1$ & & 1.6 & $33 \pm 2$ & $18 \pm 3$ \\
\hline & 5 & $109 \pm 17$ & $33 \pm 4$ & & 25 & $188 \pm 51$ & $169 \pm 24$ & & 5 & $64 \pm 6$ & $21 \pm 4$ \\
\hline 6 & 0.0 & $13 \pm 2$ & $19 \pm 3$ & 12 & 0.0 & $29 \pm 1$ & $28 \pm 4$ & 18 & 0.0 & $29 \pm 1$ & $30 \pm 7$ \\
\hline & 0.012 & $17 \pm 7$ & $17 \pm 1$ & & 0.3 & $33 \pm 12$ & $38 \pm 7$ & & 0.06 & $25 \pm 3$ & $39 \pm 2$ \\
\hline & 0.037 & $27 \pm 1$ & $22 \pm 9$ & & 0.92 & $56 \pm 5$ & $36 \pm 4$ & & 0.18 & $33 \pm 5$ & $35 \pm 3$ \\
\hline$(-)$ & 0.11 & $14 \pm 7$ & $29 \pm 14$ & $(+)^{*}$ & 2.7 & $90 \pm 1$ & $41 \pm 3$ & $(-)$ & 0.5 & $31 \pm 8$ & $32 \pm 7$ \\
\hline & 0.33 & $26 \pm 2$ & $17 \pm 4$ & & 8.3 & $287 \pm 28$ & $42 \pm 6$ & & 1.6 & $39 \pm 10$ & $37 \pm 4$ \\
\hline & 1 & $39 \pm 11$ & $19 \pm 4$ & & 25 & $352 \pm 3$ & $71 \pm 18$ & & 12.5 & $39 \pm 7$ & $32 \pm 7$ \\
\hline $\mathbf{N f} \mathbf{x}^{\mathrm{c}}$ & 0.0 & $21 \pm 4$ & $31 \pm 10$ & & & & & & & & \\
\hline & 0.5 & $29 \pm 6$ & $37 \pm 5$ & & & & & & & & \\
\hline & 1.0 & $43 \pm 17$ & $39 \pm 18$ & & & & & & & & \\
\hline$(+)$ & 3.0 & $62 \pm 2$ & $53 \pm 9$ & & & & & & & & \\
\hline & 10.0 & $144 \pm 11$ & $64 \pm 6$ & & & & & & & & \\
\hline & 30.0 & $117 \pm 17$ & $139 \pm 11$ & & & & & & & & \\
\hline
\end{tabular}

${ }^{\mathrm{a} D}$ : Doses in $\mu \mathrm{g} /$ plate. $^{\mathrm{b}}$ N.R.: Number of revertants. ${ }^{\mathrm{c}}$ Data from Toxicology letters 2009, 190 (2), 140-9.

$(+)$ : Mutagenic. (-): Not mutagenic. *Mutagenic without metabolic activation and not mutagenic with metabolic activation. 


\section{Table of Contents Graphic}

Novel quinoxaline 1,4-di- $N$-oxide derivatives as new potential antichagasic agents

Enrique Torres, Elsa Moreno-Viguri, Silvia Galiano, Goutham Devarapally, Philip W. Crawford, Amaia

Azqueta, Leire Arbillaga, Javier Varela, Estefanía Birriel, Rossanna Di Maio, Hugo Cerecetto, Mercedes

González, Ignacio Aldana, Antonio Monge, Silvia Pérez-Silanes*

Eighteen new quinoxaline 1,4-di- $N$-oxide derivatives have been synthesized and they have shown excellent in vitro biological activity against Trypanosoma cruzi, identifying one of the compounds as the most active and selective in the cytotoxicity assay.<smiles>CCOC(=O)c1c(C(F)(F)F)[n+]([O-])c2cc(F)c(F)cc2[n+]1[O-]</smiles>

$$
\begin{aligned}
& \text { PGI }(25 \mu \mathrm{M})=100.0 \% \\
& \text { IC }_{50}=0.4 \mu \mathrm{M} \\
& \text { SI }=10
\end{aligned}
$$

PGI: \% Inhibition of epimastigote growth of Tulahuen 2 strain. $\mathrm{IC}_{50}$ : concentration that inhibits $50 \%$ of epimastigote form of T. cruzi growth. SI: Selectivity Index. 